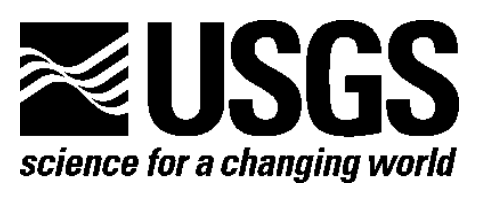

\title{
HIF Evaluation of In-Situ Aqua TROLL 400
}

By Evan F. Tillman

Open-File Report 2017-1086

U.S. Department of the Interior U.S. Geological Survey 


\section{U.S. Department of the Interior \\ RYAN K. ZINKE, Secretary}

\section{U.S. Geological Survey \\ William H. Werkheiser, Acting Director}

U.S. Geological Survey, Reston, Virginia: 2017

For more information on the USGS—-the Federal source for science about the Earth, its natural and living resources, natural hazards, and the environment-visit https://www.usgs.gov/ or call 1-888-ASK-USGS (1-888-275-8747).

For an overview of USGS information products, including maps, imagery, and publications, visit https://store.usgs.gov/.

Any use of trade, firm, or product names is for descriptive purposes only and does not imply endorsement by the U.S. Government.

Although this information product, for the most part, is in the public domain, it also may contain copyrighted materials as noted in the text. Permission to reproduce copyrighted items must be secured from the copyright owner.

Suggested citation:

Tillman, E.F., 2017, HIF evaluation of In-Situ Aqua TROLL 400: U.S. Geological Survey Open-File Report, 2017-1086, 35 p., https://doi.org/10.3133/ofr20171086. 


\section{Contents}

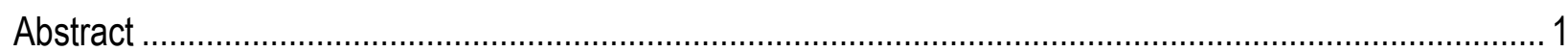

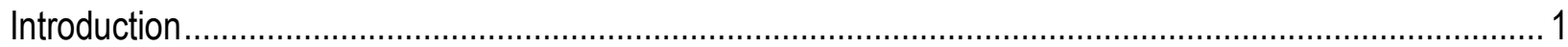

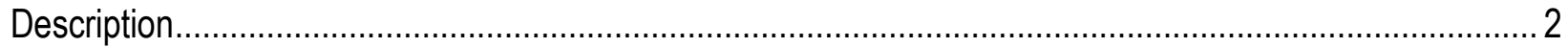

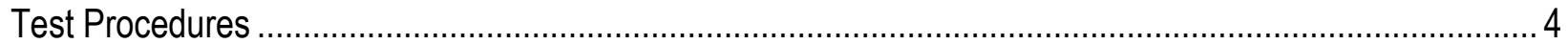

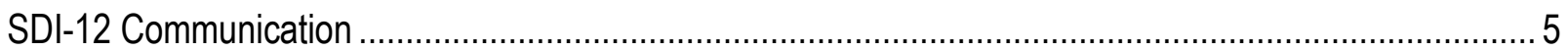

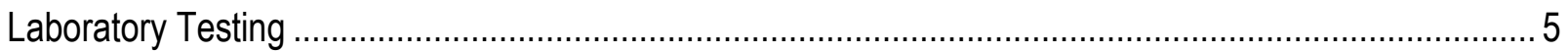

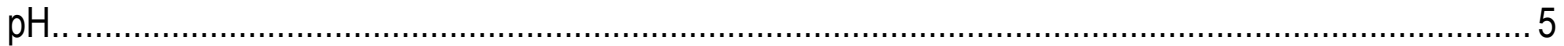

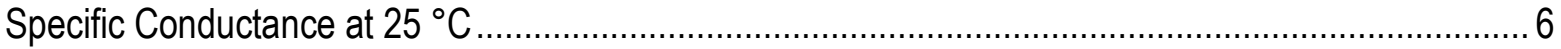

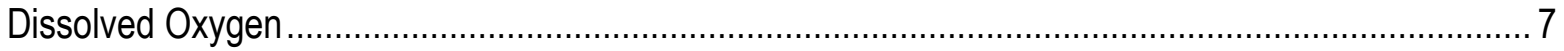

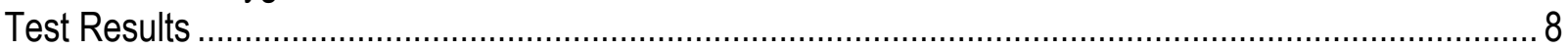

$\mathrm{pH}$

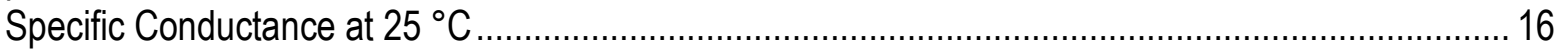

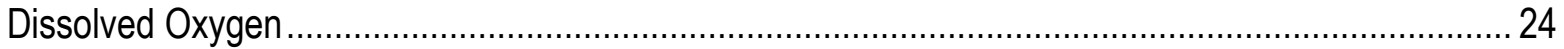

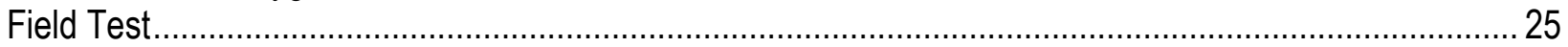

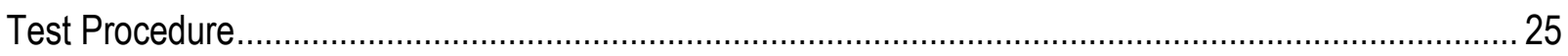

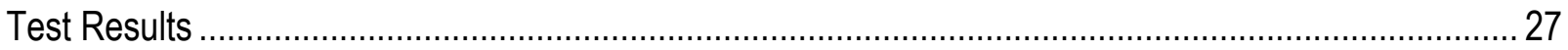

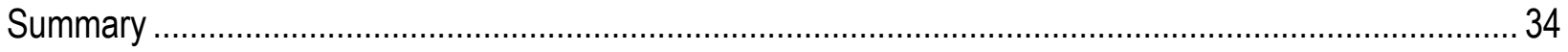

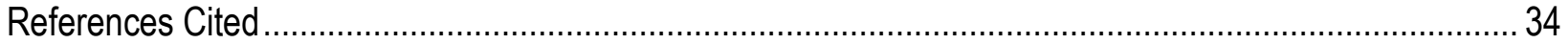

\section{Figures}

1. Photograph of the In-Situ Aqua TROLL 400 with $\mathrm{pH}$, conductance, temperature, and rugged dissolved oxygen sensors .................................................................................... 2

2. Photograph of the In-Situ Aqua TROLL 400 Rugged Dissolved Oxygen sensor ............................. 3

3. Graph showing difference in pH units between an In-Situ Aqua TROLL 400 (serial number 330074) $\mathrm{pH}$ sensor calibrated at two $\mathrm{pH}$ ranges and $\mathrm{pH}$ standards at 4 degrees Celsius plotted with manufacturer and the U.S. Geological Survey "National Field Manual for the Collection of Water-Quality Data" (NFM) accuracy limits.

4. Graph showing difference in pH units between an In-Situ Aqua TROLL 400 (serial number 329995) $\mathrm{pH}$ sensor calibrated at two $\mathrm{pH}$ ranges and $\mathrm{pH}$ standards at 4 degrees Celsius plotted with manufacturer and the U.S. Geological Survey "National Field Manual for the Collection of Water-Quality Data" (NFM) accuracy limits

5. Graph showing difference in $\mathrm{pH}$ units between an In-Situ Aqua TROLL 400 (serial number 329995) pH sensor calibrated at two pH ranges and pH standards at 15 degrees Celsius plotted with manufacturer and the U.S. Geological Survey "National Field Manual for the Collection of Water-Quality Data" (NFM) accuracy limits

6. Graph showing difference in $\mathrm{pH}$ units between an In-Situ Aqua TROLL 400 (serial number 330074) pH sensor calibrated at two pH ranges and pH standards at 15 degrees Celsius plotted with manufacturer and the U.S. Geological Survey "National Field Manual for the Collection of Water-Quality Data" (NFM) accuracy limits

7. Graph showing difference in $\mathrm{pH}$ units between an In-Situ Aqua TROLL 400 (serial number 329995) $\mathrm{pH}$ sensor calibrated at two pH ranges and pH standards at 25 degrees Celsius plotted with manufacturer and the U.S. Geological Survey "National Field Manual for the Collection of Water-Quality Data" (NFM) accuracy limits 
8. Graph showing difference in $\mathrm{pH}$ units between an In-Situ Aqua TROLL 400 (serial number 330074) pH sensor calibrated at two $\mathrm{pH}$ ranges and pH standards at 25 degrees Celsius plotted with manufacturer and the U.S. Geological Survey "National Field Manual for the Collection of Water-Quality Data" (NFM) accuracy limits.

9. Graph showing difference in $\mathrm{pH}$ units between an In-Situ Aqua TROLL 400 (serial number 329995) $\mathrm{pH}$ sensor calibrated at two $\mathrm{pH}$ ranges and $\mathrm{pH}$ standards at 40 degrees Celsius plotted with manufacturer and the U.S. Geological Survey "National Field Manual for the Collection of Water-Quality Data" (NFM) accuracy limits....

10. Graph showing difference in pH units between an In-Situ Aqua TROLL 400 (serial number 330074) pH sensor calibrated at two $\mathrm{pH}$ ranges and $\mathrm{pH}$ standards at 40 degrees Celsius plotted with manufacturer and the U.S. Geological Survey "National Field Manual for the Collection of Water-Quality Data" (NFM) accuracy limits

11. Graph showing percent difference between an In-Situ Aqua TROLL 400 (serial number 329995) specific conductance sensor and specific conductance standards at 4 degrees Celsius plotted with manufacturer and the U.S. Geological Survey "National Field Manual for the Collection of Water-Quality Data" (NFM) accuracy limits.

12. Graph showing percent difference between an In-Situ Aqua TROLL 400 (serial number 330074) specific conductance sensor and specific conductance standards at 4 degrees Celsius plotted with manufacturer and the U.S. Geological Survey "National Field Manual for the Collection of Water-Quality Data" (NFM) accuracy limits.

13. Graph showing percent difference between an In-Situ Aqua TROLL 400 (serial number 329995) specific conductance sensor and specific conductance standards at 15 degrees Celsius plotted with manufacturer and the U.S. Geological Survey "National Field Manual for the Collection of Water-Quality Data" (NFM) accuracy limits.

14. Graph showing percent difference between an In-Situ Aqua TROLL 400 (serial number 330074) specific conductance sensor and specific conductance standards at 15 degrees Celsius plotted with manufacturer and the U.S. Geological Survey "National Field Manual for the Collection of Water-Quality Data" (NFM) accuracy limits.

15. Graph showing percent difference between an In-Situ Aqua TROLL 400 (serial number 329995) specific conductance sensor and specific conductance standards at 25 degrees Celsius plotted with manufacturer and the U.S. Geological Survey "National Field Manual for the Collection of Water-Quality Data" (NFM) accuracy limits.

16. Graph showing percent difference between an In-Situ Aqua TROLL 400 (serial number 330074) specific conductance sensor and specific conductance standards at 25 degrees Celsius plotted with manufacturer and the U.S. Geological Survey "National Field Manual for the Collection of Water-Quality Data" (NFM) accuracy limits.

17. Graph showing percent difference between an In-Situ Aqua TROLL 400 (serial number 329995) specific conductance sensor and specific conductance standards at 40 degrees Celsius plotted with manufacturer and the U.S. Geological Survey "National Field Manual for the Collection of Water-Quality Data" (NFM) accuracy limits.

18. Graph showing percent difference between an In-Situ Aqua TROLL 400 (serial number 330074) specific conductance sensor and specific conductance standards at 40 degrees Celsius plotted with manufacturer and the U.S. Geological Survey "National Field Manual for the Collection of Water-Quality Data" (NFM) accuracy limits.

19. Graph showing difference in milligrams per liter ( $\mathrm{mg} / \mathrm{L}$ ) between two In-Situ Aqua TROLL $400 \mathrm{RDO}$ sensors (serial numbers 329995 and 330074) and theoretical dissolved oxygen concentrations 
plotted with manufacturer and the U.S. Geological Survey "National Field Manual for the Collection of Water-Quality Data" (NFM) accuracy limits

20. Graphs showing A, Temperature differences between an In-Situ Aqua TROLL 400 test sonde and the site sonde at U.S. Geological Survey (USGS) station 02492620 (Pearl River at National Space Technology Laboratories [NSTL] Station, Mississippi) versus time (6 weeks), and B, Temperature versus time for the site sonde and a YSI 6920 V2-2 Quality Control (QC) sonde .....

21. Graphs showing A, pH differences between an In-Situ Aqua TROLL 400 test sonde and the site sonde at U.S. Geological Survey station (USGS) 02492620 (Pearl River at National Space Technology Laboratories [NSTL] Station, Mississippi) versus time (6 weeks), and B, pH versus time for the site sonde and a YSI 6920 V2-2 Quality Control (QC) sonde

22. Graphs showing A, Specific conductance percent differences between an In-Situ Aqua TROLL 400 test sonde and the site sonde at U.S. Geological Survey (USGS) station 02492620 (Pearl River at National Space Technology Laboratories [NSTL] Station, Mississippi) versus time (6 weeks), and B, Specific conductance vs. time for the site sonde and a YSI 6920 V2-2 Quality Control (QC) sonde

23. Graphs showing A, Dissolved oxygen differences between an In-Situ Aqua TROLL 400 test sonde and the site sonde at U.S. Geological Survey (USGS) station 02492620 (Pearl River at National Space Technology Laboratories [NSTL] Station, Mississippi) versus time ( 6 weeks), and $B$, Dissolved oxygen vs. time for the site sonde and a YSI 6920 V2-2 Quality Control (QC) sonde

\section{Tables}

1. In-Situ Aqua TROLL 400 manufacturer specifications (In-Situ, 2016)

2. The pH standards used for testing of the In-Situ Aqua TROLL $400 \mathrm{pH}$ sensor and standard specifications at $25^{\circ} \mathrm{C}$

3. Conductance standards used for testing of the In-Situ Aqua TROLL 400 conductance sensor and standard specifications at $25^{\circ} \mathrm{C}$

4. Dissolved oxygen reference standards.

5. Acceptance criteria for field comparison testing of the In-Situ Aqua TROLL 400 sonde and the Hydrolab Data Sonde 5 site sonde

6. Summary statistics for the test sonde, an In-Situ Aqua TROLL 400 (serviced biweekly), and the site sonde, a Hydrolab Data Sonde 5 (serviced every week), at U.S. Geological Survey Station 02492620 Pearl River at National Space Technology Laboratories (NSTL) Station, Mississippi, over a 6-week deployment....

7. Fouling- and calibration-drift corrections for an In-Situ Aqua TROLL 400 after a 6-week deployment at U.S. Geological Survey Station 02492620 Pearl River at National Space Technology Laboratories (NSTL) Station, Mississippi, with maintenance every 2 weeks

8. Accuracy ratings of continuous water-quality records, reprinted from U.S. Geological Survey Techniques and Methods 1-D3, table 18, 2006 


\section{Conversion Factors}

SI to Inch/Pound

\begin{tabular}{|c|c|c|}
\hline Multiply & By & To obtain \\
\hline \multicolumn{3}{|c|}{ Length } \\
\hline millimeter $(\mathrm{mm})$ & 0.03937 & inch (in.) \\
\hline centimeter $(\mathrm{cm})$ & 0.3937 & inch (in.) \\
\hline meter $(\mathrm{m})$ & 3.281 & foot $(\mathrm{ft})$ \\
\hline \multicolumn{3}{|c|}{ Volume } \\
\hline liter (L) & 33.82 & ounce, fluid (fl. oz) \\
\hline liter (L) & 2.113 & pint (pt) \\
\hline liter (L) & 1.057 & quart (qt) \\
\hline liter (L) & 0.2642 & gallon (gal) \\
\hline \multicolumn{3}{|c|}{ Mass } \\
\hline gram $(\mathrm{g})$ & 0.03527 & ounce, avoirdupois (oz) \\
\hline kilogram $(\mathrm{kg})$ & 2.205 & pound avoirdupois (lb) \\
\hline \multicolumn{3}{|c|}{ Pressure } \\
\hline kilopascal (kPa) & 0.009869 & atmosphere, standard (atm) \\
\hline kilopascal (kPa) & 0.01 & bar \\
\hline kilopascal $(\mathrm{kPa})$ & 0.2961 & inch of mercury at $60^{\circ} \mathrm{F}$ (in $\mathrm{Hg}$ ) \\
\hline
\end{tabular}

Temperature in degrees Celsius $\left({ }^{\circ} \mathrm{C}\right)$ may be converted to degrees Fahrenheit $\left({ }^{\circ} \mathrm{F}\right)$ as follows:

$$
{ }^{\circ} \mathrm{F}=\left(1.8 \times{ }^{\circ} \mathrm{C}\right)+32 \text {. }
$$

Specific conductance is given in microsiemens per centimeter at 25 degrees Celsius $\left(\mu \mathrm{S} / \mathrm{cm}\right.$ at $\left.25^{\circ} \mathrm{C}\right)$.

Concentrations of chemical constituents in water are given in milligrams per liter (mg/L).

\section{Abbreviations}

DO

U.S. Geological Survey Hydrologic Instrumentation Facility

$\mathrm{KCl} \quad$ potassium chloride

NFM U.S. Geological Survey "National Field Manual for the Collection of Water-Quality Data"

NIST National Institute of Standards and Technology

ORP oxidation reduction potential

QC quality control

RDO rugged dissolved oxygen

SC specific conductance

USGS U.S. Geological Survey 


\title{
HIF Evaluation of In-Situ Aqua TROLL 400
}

\author{
By Evan Tillman
}

\section{Abstract}

The In-Situ Aqua TROLL 400 (Aqua TROLL 400) was tested at the U.S. Geological Survey (USGS) Hydrologic Instrumentation Facility (HIF) against known standards over the Aqua TROLL 400's operating temperature to verify the manufacturer's stated accuracy specifications and the USGS recommendations for $\mathrm{pH}$, dissolved oxygen (DO), and specific conductance (SC). The Aqua TROLL 400 manufacturer's specifications are within the USGS recommendations for all parameters tested, except for DO, which is outside the USGS recommendation at DO concentrations of 8.0 milligrams per liter $(\mathrm{mg} / \mathrm{L})$ and higher. The Aqua TROLL 400 was compliant with Serial Digital Interface at 1200 baud (SDI-12) version 1.3. During laboratory testing of $\mathrm{pH}$, the Aqua TROLL 400 sonde met the U.S. Geological Survey "National Field Manual for the Collection of Water-Quality Data" (NFM) recommendations for $\mathrm{pH}$ at all values tested, except at 4 degrees Celsius $\left({ }^{\circ} \mathrm{C}\right)$ at $\mathrm{pH} 9.395$ and $\mathrm{pH}$ 3.998. The Aqua TROLL 400 met the manufacturer specifications for $\mathrm{pH}$ at all values tested, except for $\mathrm{pH}$ buffers 3.998, 9.395, and 10.245 at $4{ }^{\circ} \mathrm{C}$; $\mathrm{pH} 2.990$ and 3.998 at $15^{\circ} \mathrm{C}$; and $\mathrm{pH} 3.040$ at $40{ }^{\circ} \mathrm{C}$. The Aqua TROLL 400 met the NFM recommendations at 93.7 percent of the SC values tested and met the manufacturer's accuracy specifications at 56.3 percent of the SC values tested. During the laboratory testing for DO, the Aqua TROLL 400 met the manufacturer specifications, except at $5.55 \mathrm{mg} / \mathrm{L}$, and met the NFM recommendations at all concentrations tested. An Aqua TROLL 400 was field tested at USGS Station 02492620, National Space Technology Laboratories (NSTL) Station, Mississippi, on the Pearl River for 6 weeks and showed good agreement with the well-maintained site sonde data for $\mathrm{pH}, \mathrm{DO}$, temperature, and SC.

\section{Introduction}

The U.S. Geological Survey (USGS) Hydrologic Instrumentation Facility (HIF) evaluates the performance of instruments and equipment that are used to measure hydrologic data. These devices may measure parameters needed to quantify streamflow, to monitor groundwater levels, or to quantify water quality in a variety of field settings. Evaluations test whether the instrument meets the performance criteria listed in the manufacturer's literature for the selected, tested features. Evaluations are performed primarily to help facilitate the decision-making process when selecting appropriate instruments and equipment for use in the field. The instrument performance at the time of testing may or may not represent future performance resulting from firmware updates and improvements to the instrument. Reports describing the instrument evaluation are not indicative of an endorsement by the USGS of the tested instrument. The findings in this report are based upon the Win-Situ 5 control software version 5.6.22.4 and sonde firmware version 1.11. This report documents the laboratory and field evaluation of the In-Situ 
Aqua TROLL 400. After a brief description of the sonde model, the communication, laboratory, and field test procedures and results are described.

\section{Description}

The Aqua TROLL 400 from In-Situ Inc. (http://www.in-situ.com) includes pH/oxidation reduction potential ( $\mathrm{pH} / \mathrm{ORP}$ ), conductance, In-Situ's rugged dissolved oxygen (RDO) temperature, and pressure sensors (fig. 1). The RDO (fig. 2), temperature, and conductance sensors are integrated into the body of the Aqua TROLL 400. The pH/ORP sensor is replaceable. The Aqua TROLL 400 requires an external power supply, and does not log internally. For logging purposes, the Aqua TROLL provides Modbus/RS485 and Serial Digital Interface at 1200 baud (SDI-12) interfaces. The Aqua TROLL 400 may be used for unattended monitoring and is designed for surface-water and groundwater applications. Setup is with In-Situ's Comm Cable Connect and a computer running Win-Situ 5 software (ver. 5.6.22.4 used during evaluation) or with a communication kit (Comm Kit; part number 0081100, not used during this evaluation) and a computer running In-Situ's Comm Kit software. The Aqua TROLL 400 as tested used firmware version 1.11 and SDI-12 version 1.3.

The $\mathrm{pH}$ sensor's reference electrode is refillable and has a replaceable Teflon junction. The Aqua TROLL 400 measures conductance and temperature, and uses Standard Methods $2510 \mathrm{~B}$ (Eaton and others, 2005) to correct the conductance sensor measurement to specific conductance (SC) at 25 degrees $\left({ }^{\circ} \mathrm{C}\right)$ Celsius. All measurements with the conductance sensor are in specific conductance and throughout the paper the sensor is referred to as a specific conductance sensor. The software in the Aqua TROLL 400 will also compute salinity and total dissolved solids from the SC sensor measurements. The RDO sensor is a luminescence-based optical sensor with a replaceable sensor cap. The RDO sensor cap has a life of 24 months from the date of manufacture, or 12 months from the first reading, whichever comes first. The sensor cap has a memory chip with the calibration coefficients and the date of manufacture, and stores the date of first use. Unlike some replaceable DO caps, the RDO cap does not need to be hydrated to work correctly.

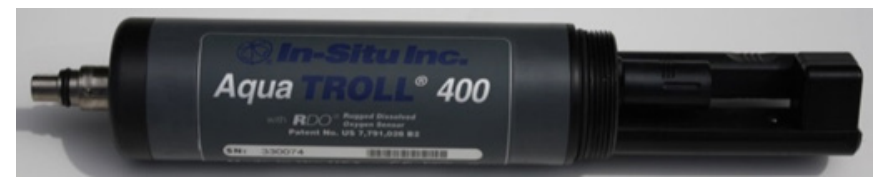

Figure 1. Photograph of the In-Situ Aqua TROLL 400 with $\mathrm{pH}$, conductance, temperature, and rugged dissolved oxygen sensors. 


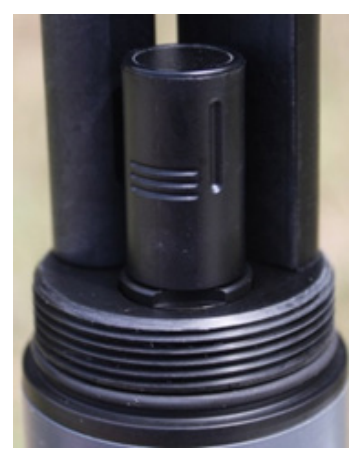

Figure 2. Photograph of the In-Situ Aqua TROLL 400 Rugged Dissolved Oxygen sensor.

The manufacturer's specifications for the Aqua TROLL 400 are listed in table 1 (In-Situ, 2016). The manufacturer's accuracy specifications comply with the recommendations in chapter A6 of the U.S. Geological Survey "National Field Manual for the Collection of Water-Quality Data" (NFM) for $\mathrm{pH}$ and SC. The manufacturer's accuracy specifications for dissolved oxygen (DO) comply with the NFM recommendations up to 200 milligrams per liter (mg/L) and are outside the limits of the NFM recommendations at $20 \mathrm{mg} / \mathrm{L}$ and above.

Table 1. In-Situ Aqua TROLL 400 manufacturer specifications (In-Situ, 2016).

[PVC, polyvinyl chloride; SS, stainless steel; cm, centimeter; in, inch; dia, diameter; g, gram; lb, pound; VDC, volts direct current; $\mathrm{mA}$, milliamps; $\mu \mathrm{A}$, microamps; $\mathrm{AC}$, alternating current; psi, pounds per square inch; $\mathrm{m}$, meter; $\mathrm{ft}$, feet; ${ }^{\circ} \mathrm{C}$, degree Celsius; ${ }^{\circ} \mathrm{F}$, degree Fahrenheit; SDI-12, Serial Data Interface at 1200 baud; $\mu$ S/cm, microsiemens per centimeter; $\mathrm{mS} / \mathrm{cm}$, millisiemens per centimeter; ORP, oxidation reduction potential; $\mathrm{mV}$, milliVolts; RDO, rugged dissolved oxygen; \%, percent; mg/L, milligram per liter; $\mathrm{kPa}$, kilopascal; mbar, millibar; mmHg, millimeters mercury; mm, millimeter; FS, full scale]

\begin{tabular}{|c|c|}
\hline Feature & Specification \\
\hline \multicolumn{2}{|r|}{ General } \\
\hline Housing material & $\begin{array}{l}\text { PVC, titanium, Viton } \AA \text {, acetal, and 316L SS/ } \\
\text { polycarbonate/Poly(methyl methacrylate) }\end{array}$ \\
\hline Dimensions & $4.7 \mathrm{~cm}$ (1.85 in.) dia x $26.9 \mathrm{~cm}$ (10.6 in.) long \\
\hline Weight (sensors) & $694 \mathrm{~g}(1.53 \mathrm{lbs})$ \\
\hline \multicolumn{2}{|l|}{ Power } \\
\hline Internal & None \\
\hline External & 8-36 VDC \\
\hline Measurement current & $16 \mathrm{~mA}$ at $24 \mathrm{VDC}$ \\
\hline Sleep current & $40 \mu \mathrm{A}$ at $24 \mathrm{VDC}$ \\
\hline Maximum pressure rating & 160 psi; 112 m (668 ft) \\
\hline Temperature operating range & $-5^{\circ} \mathrm{C}$ to $50^{\circ} \mathrm{C}\left(23^{\circ} \mathrm{F}\right.$ to $\left.122^{\circ} \mathrm{F}\right)$ \\
\hline Communication & Output: Modbus/RS-485 or SDI-12 \\
\hline \multicolumn{2}{|c|}{ Specific conductance sensor ${ }^{1}$} \\
\hline Type & Six-cell conductance \\
\hline Units & $\mu \mathrm{S} / \mathrm{cm}, \mathrm{mS} / \mathrm{cm}$ \\
\hline Range & $5 \mu \mathrm{S} / \mathrm{cm}$ to $100,000 \mu \mathrm{S} / \mathrm{cm}$ \\
\hline Accuracy & $\pm 0.5 \%+1 \mu \mathrm{S} / \mathrm{cm} ;$ maximum $\pm 1 \%$ \\
\hline Resolution & $0.1 \mu \mathrm{S} / \mathrm{cm}$ \\
\hline
\end{tabular}




\begin{tabular}{|c|c|}
\hline \multicolumn{2}{|r|}{$\mathrm{pH}$ sensor } \\
\hline Type & $\begin{array}{l}\text { Glass sensing bulb, single-junction electrode, replaceable } \\
\text { ceramic junction, refillable reference electrolyte }\end{array}$ \\
\hline Units & Standard $\mathrm{pH}$ units \\
\hline Range & 0 to $12 \mathrm{pH}$ units \\
\hline Accuracy & $\pm 0.1 \mathrm{pH}$ unit \\
\hline Resolution & $0.01 \mathrm{pH}$ unit \\
\hline \multicolumn{2}{|r|}{ ORP sensor } \\
\hline Range & $\pm 1400 \mathrm{mV}$ \\
\hline Units & $\mathrm{mV}$ \\
\hline Accuracy & $\pm 5.0 \mathrm{mV}$ \\
\hline Resolution & $0.1 \mathrm{mV}$ \\
\hline \multicolumn{2}{|c|}{ Dissolved oxygen (optical, RDO) sensor } \\
\hline Type & Optical luminescence quenching \\
\hline Units & $\%$, percent saturation; $\mathrm{mg} / \mathrm{L}$ \\
\hline Range & 0 to $50 \mathrm{mg} / \mathrm{L}$ \\
\hline \multirow[t]{3}{*}{ Accuracy } & $\pm 0.1 \mathrm{mg} / \mathrm{L} @ 0-8 \mathrm{mg} / \mathrm{L}$ \\
\hline & \pm 0.2 mg/L@8-20mg/L \\
\hline & $\pm 10 \%$ of reading $@ 20-50 \mathrm{mg} / \mathrm{L}$ \\
\hline Resolution & $0.01 \mathrm{mg} / \mathrm{L}$ \\
\hline \multicolumn{2}{|c|}{ Level, depth, and pressure } \\
\hline Type & Piezoresistive ceramic pressure sensor \\
\hline \multirow[t]{2}{*}{ Units } & Pressure: psi, kPa, bar, mbar, mmHg \\
\hline & Level: $\mathrm{mm}, \mathrm{cm}, \mathrm{m}$, in., $\mathrm{ft}$ \\
\hline Range & 75 m (250 ft); absolute (nonvented) \\
\hline \multirow[t]{2}{*}{ Accuracy } & $\pm 0.1 \% \mathrm{FS}$ at $15^{\circ} \mathrm{C}$ \\
\hline & $\pm 0.3 \% \mathrm{FS}$ maximum from 0 to $50^{\circ} \mathrm{C}$ \\
\hline Resolution & $\pm 0.01 \mathrm{FS}$ \\
\hline \multicolumn{2}{|c|}{ Temperature sensor } \\
\hline Type & Thermistor \\
\hline Units & ${ }^{\circ} \mathrm{C},{ }^{\circ} \mathrm{F}$ \\
\hline Range & $-5^{\circ} \mathrm{C}$ to $50^{\circ} \mathrm{C}\left(23^{\circ} \mathrm{F}\right.$ to $\left.122^{\circ} \mathrm{F}\right)$ \\
\hline Accuracy & $\pm 0.1^{\circ} \mathrm{C}$ \\
\hline Resolution & $0.01^{\circ} \mathrm{C}$ \\
\hline \multicolumn{2}{|c|}{ Operating software } \\
\hline
\end{tabular}

Win-Situ 5 - software version 5.6.22.4

In-Situ Aqua TROLL 400 Firmware version 1.11

${ }^{1}$ Specific conductance readings are equal to conductance at $25^{\circ} \mathrm{C}$.

\section{Test Procedures}

The Aqua TROLL 400 from In-Situ Inc. was tested for compliance with the SDI-12 communication standard. To evaluate compliance with the USGS's accuracy requirements and the manufacturer's stated accuracy specifications for $\mathrm{pH}$, DO, and SC, the Aqua TROLL 400 was tested against known standards in a controlled laboratory environment. To evaluate 
performance and calibration drift over time, an Aqua TROLL 400 from the laboratory test was field tested at the HIF's Pearl River testing site. A cursory comparison of temperature against a known reference was performed during the testing. The pressure and ORP sensors were not tested. In this report, differences are computed as sensor measurement minus the reference value, or difference $=$ sensor - reference. For laboratory tests, the reference was the value of the standard and the permanently installed and maintained site sonde at USGS Station 02492620 was the reference for the field deployment.

\section{SDI-12 Communication}

The Aqua TROLL 400's SDI-12 function was checked using an NR Systems SDI-12 Verifier, software version 5.0.0.24, and Verifier firmware 1.6. The verifier's "Comprehensive Sensor Test" function was selected for this test. The verifier checks SDI-12 sensors by sending commands to the sensor under test. It verifies all responses, checking for the correct responses within the specified time constraints. The verifier does not check the electrical compliance of the device and no additional testing for SDI-12 electrical compliance was conducted. The Aqua TROLL 400 was compliant with SDI-12 version 1.3 requirements based on the verifier results.

\section{Laboratory Testing}

Testing of the $\mathrm{pH}, \mathrm{SC}$, and RDO sensors on two Aqua TROLL 400s (serial numbers 329995 [pH sensor serial number PP13986] and 330074 [pH sensor serial number PP14030]) was conducted at the HIF Water-Quality Laboratory. National Institute of Standards and Technology (NIST)-traceable chemical standards were used as known references against which $\mathrm{pH}$ and $\mathrm{SC}$ sensor performance were evaluated. Water equilibrated with an atmosphere containing varying amounts of oxygen at various temperatures was used as the known reference for DO measurements. All tests were conducted in either temperature-controlled water baths or temperature-controlled environmental test chambers, depending on the tested sensor. No specific testing of the ORP sensor or the thermistor was performed.

Additional instrumentation was used for secondary confirmation of the chemical standards and DO concentrations. The calibration and test standards' values for $\mathrm{pH}$ and $\mathrm{SC}$ were verified with a ROSS Ultra combination $\mathrm{pH}$ glass electrode (Model 8102BNUWP, accuracy $\pm 0.01 \mathrm{pH}$ units) and an Orion $5 \mathrm{Star}$ bench top meter with a four-cell graphite $\mathrm{SC}$ sensor (013605MD, accuracy \pm 0.5 percent +0.01 microsiemens per centimeter $[\mu \mathrm{S} / \mathrm{cm}])$. The Orion $\mathrm{pH}$ and SC meters were calibrated with second-source certified NIST-traceable standards.

Theoretical DO values were calculated with data from a NIST-traceable Setra Model 370 digital barometric pressure gauge $( \pm 0.02$ percent full scale $)$ and a YSI $4600\left( \pm 0.115^{\circ} \mathrm{C}\right)$ NIST-traceable thermometer, and Winklers titrations were done as an independent check of the theoretical DO concentrations.

$\mathrm{pH}$

Sensors for $\mathrm{pH}$ on two Aqua TROLL 400 sondes (serial numbers 329995 [pH sensor serial number PP13986] and 330074 [pH sensor serial number PP14030]) were tested for accuracy over a range of $\mathrm{pH}$ and temperatures in a temperature-controlled environmental test chamber. The NIST-traceable $\mathrm{pH}$ solutions used as calibration and test standards (table 2) came with temperature compensation tables and were certified at $25^{\circ} \mathrm{C}$ with an accuracy rating better than the sensor's accuracy limits. The $\mathrm{pH} 3.0$ standard temperature compensation tables only 
went from 15 to $40{ }^{\circ} \mathrm{C}$. The other $\mathrm{pH}$ compensation tables went from 4 to $40^{\circ} \mathrm{C}$. Calibration standards, test standards, and the test sonde were allowed to equilibrate overnight to the test chamber temperature prior to calibration and data collection. The Aqua TROLL 400s were tested at $4{ }^{\circ} \mathrm{C}, 15^{\circ} \mathrm{C}, 25^{\circ}$, and $40^{\circ} \mathrm{C}$ in standards $\mathrm{pH} 4.0$ to $\mathrm{pH} 10.0$ (table 2 ) and at $15^{\circ} \mathrm{C}, 25^{\circ} \mathrm{C}$, and $40{ }^{\circ} \mathrm{C}$ in $\mathrm{pH} 3.0$ standard. It was not tested with $\mathrm{pH} 3.0$ at $4{ }^{\circ} \mathrm{C}$. Differences between the Aqua TROLL's $\mathrm{pH}$ reading and the test standard value were used to determine sensor accuracy.

Table 2. The pH standards used for testing of the In-Situ Aqua TROLL $400 \mathrm{pH}$ sensor and standard specifications at $25^{\circ} \mathrm{C}$.

$\left[{ }^{\circ} \mathrm{C}\right.$, degree Celsius $]$

\begin{tabular}{ccl}
\hline pH Value & Accuracy at $25^{\circ} \mathrm{C}$ & \multicolumn{1}{c}{ Test Use } \\
\hline 1.679 & \pm 0.01 & Calibration \\
3.00 & \pm 0.01 & Measurement \\
4.005 & \pm 0.01 & Measurement \\
6.865 & \pm 0.01 & Measurement \\
7.000 & \pm 0.01 & Calibration \\
7.413 & \pm 0.01 & Measurement \\
9.180 & \pm 0.01 & Measurement \\
10.00 & \pm 0.01 & Measurement \\
11.00 & \pm 0.01 & Calibration \\
\hline
\end{tabular}

The sensor under test was calibrated at each test temperature using two $\mathrm{pH}$ calibration standards that bracketed the value of the $\mathrm{pH}$ test standard per the NFM recommendations (Ritz and Collins, 2008). Calibration standards 1.679 and 7.00 were used for test standards less than $\mathrm{pH}$ 7. Calibration standards 7.00 and 11.00 were used for test standards greater than $\mathrm{pH}$ 7. The calibration procedure was in accordance with the manufacturer's protocol for a multipoint calibration, beginning with the $\mathrm{pH} 7.00$ buffer value. During testing, the sensor was rinsed with the $\mathrm{pH}$ test standard three times at test temperature and allowed to equilibrate in the test standard for an additional 15 minutes prior to a measurement, or until the standard's temperature was $\pm 1.0 \mathrm{C}$ from the desired test temperature prior to a measurement. This rinsing and equilibration process was repeated with each test standard prior to a measurement. A YSI 4600 NISTtraceable temperature probe was used to determine the solution's temperature in the environmental chamber. A laptop running In-Situ's Comm Kit software was used to display and record the sonde's readings. Temperatures (from YSI 4600 thermometer and Aqua TROLL 400) and $\mathrm{pH}$ were recorded at 30-second intervals, 20 times for each test standard and temperature.

\section{Specific Conductance at $25^{\circ} \mathrm{C}$}

The SC sensors on two Aqua TROLL 400s (serial numbers 329995 and 330074) were tested for accuracy over a range of SC and temperatures in a controlled-environmental test chamber. Both Aqua TROLL 400s were tested over the same range of SC and temperature. Potassium chloride $(\mathrm{KCl}) \mathrm{SC}$ solutions were used as test and calibration standards (table 3 ). The solutions were NIST traceable, certified at $25^{\circ} \mathrm{C}$ with an accuracy rating better than the sensor's accuracy limits, and came with temperature compensation tables. The test Aqua TROLL 400 and the testing standards for SC were allowed to equilibrate overnight to the test chamber 
temperature prior to data collection. Sensors were tested at four test temperatures $-4,{ }^{\circ} \mathrm{C}, 15^{\circ} \mathrm{C}$, $25^{\circ} \mathrm{C}$, and $40{ }^{\circ} \mathrm{C}$ - over their $\mathrm{SC}$ range.

Each Aqua TROLL 400 was checked in air $(0 \mu \mathrm{S} / \mathrm{cm})$ and calibrated at $1,000 \mu \mathrm{S} / \mathrm{cm}$ at 25 ${ }^{\circ} \mathrm{C}$ before testing. Prior to testing, each sensor was rinsed with deionized water three times, triple rinsed with the test standard, and then allowed to equilibrate in the test standard until the standard's temperature was $\pm 0.5^{\circ} \mathrm{C}$ from the desired test temperature prior to a measurement.

A YSI 4600 NIST-traceable temperature probe was used to measure the temperature of the solutions in the environmental chamber. A laptop running In-Situ's Comm Kit software was used to display and record the readings of the sonde. The temperature (from YSI 4600 thermometer and Aqua TROLL 400) and SC were recorded at 30-second intervals, 20 times for each test standard and temperature.

Table 3. Conductance standards used for testing of the In-Situ Aqua TROLL 400 conductance sensor and standard specifications at $25^{\circ} \mathrm{C}$.

$\left[{ }^{\circ} \mathrm{C}\right.$, degree Celsius; $\mu \mathrm{S} / \mathrm{cm}$, microsiemens per centimeter $]$

\begin{tabular}{crcl}
\hline $\begin{array}{c}\text { Specific conductance } \\
\text { at } 25^{\circ} \mathrm{C} \\
(\boldsymbol{\mu S} / \mathrm{cm})\end{array}$ & \multicolumn{2}{c}{ Accuracy at $25^{\circ} \mathrm{C}$} & Test use \\
\cline { 2 - 3 } & $(\boldsymbol{\mu S} / \mathrm{cm})$ & (percent) & \\
\hline 99.9 & \pm 1.01 & \pm 1.01 & Measurement \\
$1,000.0$ & \pm 10.00 & \pm 1.00 & Calibration \\
$1,412.0$ & \pm 3.80 & \pm 0.27 & Measurement \\
$9,994.0$ & \pm 26.00 & \pm 0.26 & Measurement \\
$99,918.0$ & \pm 226.70 & \pm 0.23 & Measurement \\
\hline
\end{tabular}

\section{Dissolved Oxygen}

Dissolved oxygen accuracy was evaluated on two Aqua TROLL 400s (serial numbers 329995 and 330074) in 11 different DO concentrations created by varying the temperature at atmospheric saturations of 100 percent, 24 percent, and 0 percent oxygen (table 4). Prior to the testing, the DO sensors were calibrated at room temperature in ambient-air saturated water using the NFM (Rounds and others, 2013) and the manufacturer's recommendations. Barometric pressure was measured during testing using a NIST-traceable Setra Model 370 digital pressure gage. The temperature of the water was measured with a YSI 4600. Theoretical values for DO were computed and used as the test standard. As an independent check of the theoretical DO test concentrations, Winkler titrations were performed in accordance with Standard Methods 4500-O C Azide Modification (Eaton and others, 2005), with reagents prepared just prior to use.

The 100-percent ambient-air saturated water was evaluated at four temperatures in a mini standpipe (a 16-inch [in.] high, 6.25-in.-interior-diameter acrylic standpipe fitted with a spigot) in a temperature-controlled environmental test chamber. The Aqua TROLL 400 under test was placed vertically in the mini standpipe, and an aquarium pump and air stone were used to saturate the water with air. The entire setup was allowed to run overnight at each test temperature to ensure complete temperature equilibrium and air saturation of the solution. The DO concentrations for air-saturated water at four different temperatures $\left(4{ }^{\circ} \mathrm{C}, 13{ }^{\circ} \mathrm{C}, 22{ }^{\circ} \mathrm{C}\right.$, and $50^{\circ} \mathrm{C}$ ) were measured twice by each Aqua TROLL 400 and compared to duplicated Winkler titration values collected immediately from the standpipe. Theoretical values for the oxygen 
concentration of each of the 100-percent ambient-air saturated solutions tested were calculated (Benson and Krause, 1980).

The 24-percent DO saturation solution was created by closing off the top of the mini standpipe with parafilm at room temperature. Prior to each DO measurement, an air stone was used to sparge the water with 95-percent nitrogen and a 5-percent oxygen gas mixture for at least 1 hour. The DO concentration of the water bath was measured twice by each Aqua TROLL 400 and compared to duplicated Winkler titration values collected immediately from the mini standpipe's spigot. The theoretical value for the oxygen concentration of the 24-percent saturated DO solution was calculated with Henry's Law (Henry, 1803) using measured values of barometric pressure and water temperature. The water bath was at room temperature $\left(22{ }^{\circ} \mathrm{C}\right)$ and the barometric pressure was 762 millimeters $(\mathrm{mm})$ of mercury $(\mathrm{mmHg})$. The corresponding Henry's Law constant was calculated to be 726 liters (L) per atmosphere $/ \mathrm{mole}(\mathrm{L} * \mathrm{~atm} / \mathrm{mol})$ and this yielded a calculated DO concentration of $2.2(\mathrm{mg} / \mathrm{L})$.

The 0-percent DO saturation solution was created by closing off the top of the mini standpipe with parafilm. Prior to DO measurement, an air stone was used to sparge the water with dry nitrogen gas for at least 1 hour at room temperature. DO concentration of the water bath was measured twice by the Aqua TROLL 400 under test and recorded. Two samples were collected from the mini standpipe's spigot immediately after each DO measurement and a Winkler titration was performed on each sample. The temperature of the water bath $\left(22{ }^{\circ} \mathrm{C}\right)$ was measured with a YSI 4600. The theoretical value of oxygen saturation of the test solution was assumed to be zero and was verified by the Winkler samples.

Table 4. Dissolved oxygen reference standards.

[DO, dissolved oxygen; mmHg, millimeters mercury; NA, not applicable; ${ }^{\circ} \mathrm{C}$, degrees Celsius; mg/L, milligram per liter; \%, percent; $\mathrm{N}_{2}$, nitrogen; $\mathrm{O}_{2}$, oxygen]

\begin{tabular}{ccccc}
\hline $\begin{array}{c}\text { Do saturation } \\
\text { (percent) }\end{array}$ & $\begin{array}{c}\text { Barometric } \\
\text { pressure } \\
(\mathrm{mmHg})\end{array}$ & $\begin{array}{c}\text { Water bath } \\
\text { temperature }\left({ }^{\circ} \mathrm{C}\right)\end{array}$ & $\begin{array}{c}\text { Theoretical DO } \\
(\mathrm{mg} / \mathrm{L})\end{array}$ & Source gas \\
\hline $100^{1}$ & $\mathrm{NA}$ & 4 & 13.20 & Atmosphere \\
& & 13 & 10.47 & \\
& 22 & 8.70 & \\
$24^{2}$ & 20 & 5.55 & \\
0 & 762 & 22 & 2.20 & $95 \% \mathrm{~N}_{2}, 5 \% \mathrm{O}_{2}$ \\
& $\mathrm{NA}$ & 22 & 0.00 & $100 \% \mathrm{~N}_{2}$ \\
\hline
\end{tabular}

${ }^{1}$ Theoretical values determined from Benson and Krause dissolved oxygen equation for freshwater.

${ }^{2}$ Theoretical values determined from Henry's Law.

\section{Test Results}

Test results are presented in plots of error with vertical error bars by sensor type and test temperatures. The error bars for each parameter tested were calculated assuming the calibration and test standards' accuracy ranges were for two standard deviations and were limited to a rectangular probability distribution (United Kingdom Accreditation Service, 2007). The uncertainty value used for the wet chemistry Winklers' error bars was a standard deviation of $\pm 0.020 \mathrm{mg} / \mathrm{L}$ listed in Method 4005-O C (Eaton, 2005). While no specific testing of the 
thermistor was performed, the Aqua TROLL's thermistor did perform within the expected accuracy limits of the test setup $\left( \pm 1.2^{\circ} \mathrm{C}\right)$.

$\mathrm{pH}$

Figures 3 through 10 show the differences between the mean $\mathrm{pH}$ values from two Aqua TROLL 400 s and the known test standard $\mathrm{pH}$ values at $4{ }^{\circ} \mathrm{C}, 15^{\circ} \mathrm{C}, 25^{\circ} \mathrm{C}$, and $40^{\circ} \mathrm{C}$. Differences are plotted with error bars that reflect the overall combined uncertainty of the standards accuracy. The two Aqua TROLL 400s met the NFM recommendations for $\mathrm{pH}$ at all values tested, except at $4{ }^{\circ} \mathrm{C}$, where 329995 (fig. 3) exceeded the NFM recommendations at pH 9.395, and 330074 (fig. 4) exceeded the NFM recommendations and the manufacturer specifications at $\mathrm{pH} 3.998$. At $4{ }^{\circ} \mathrm{C}, 329995$ exceeded the manufacturer specifications in $\mathrm{pH}$ buffer 3.998, 9.395, and 10.245. At $15^{\circ} \mathrm{C}, 329995$ (fig. 5) met the NFM recommendations and the manufacturer specifications for $\mathrm{pH}$ at all values tested and 330074 (fig. 6) exceeded the manufacturer specifications in $\mathrm{pH} 2.990$ and 3.998. At $25^{\circ} \mathrm{C}, 329995$ (fig. 7) and 330074 (fig. 8) met the NFM recommendations and the manufacturer specifications for $\mathrm{pH}$ at all values tested. At $40{ }^{\circ} \mathrm{C}, 329995$ (fig. 9) met the NFM recommendations and the manufacturer specifications for $\mathrm{pH}$ at all values tested and 330074 (fig. 10) exceeded the manufacturer specifications in $\mathrm{pH} 3.040$.

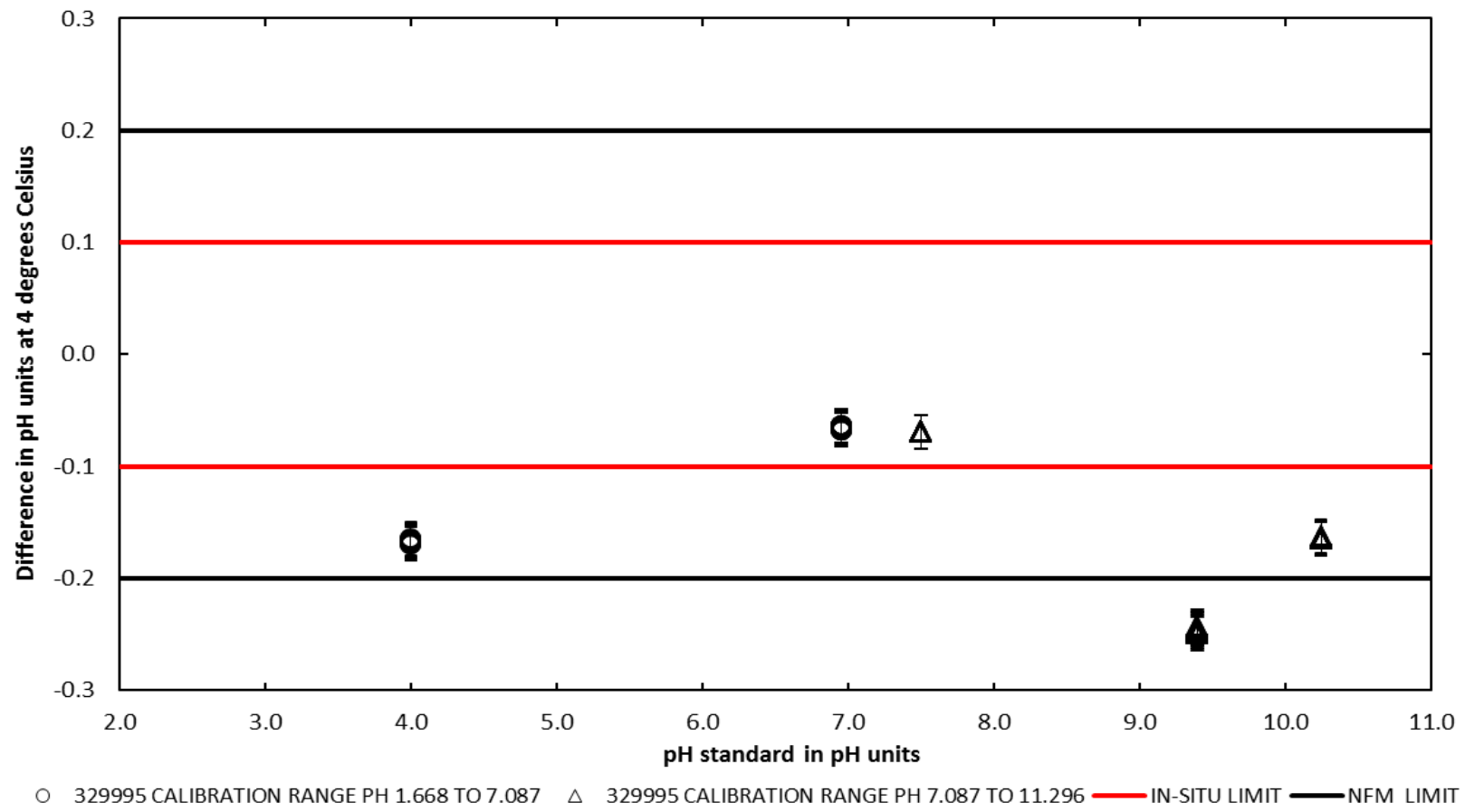

Figure 3. Graph showing difference in pH units between an In-Situ Aqua TROLL 400 (serial number 329995) pH sensor calibrated at two pH ranges and $\mathrm{pH}$ standards at 4 degrees Celsius plotted with manufacturer and the U.S. Geological Survey "National Field Manual for the Collection of Water-Quality Data" (NFM) accuracy limits. Error bars reflect the combined accuracy of the calibration and test standards. 


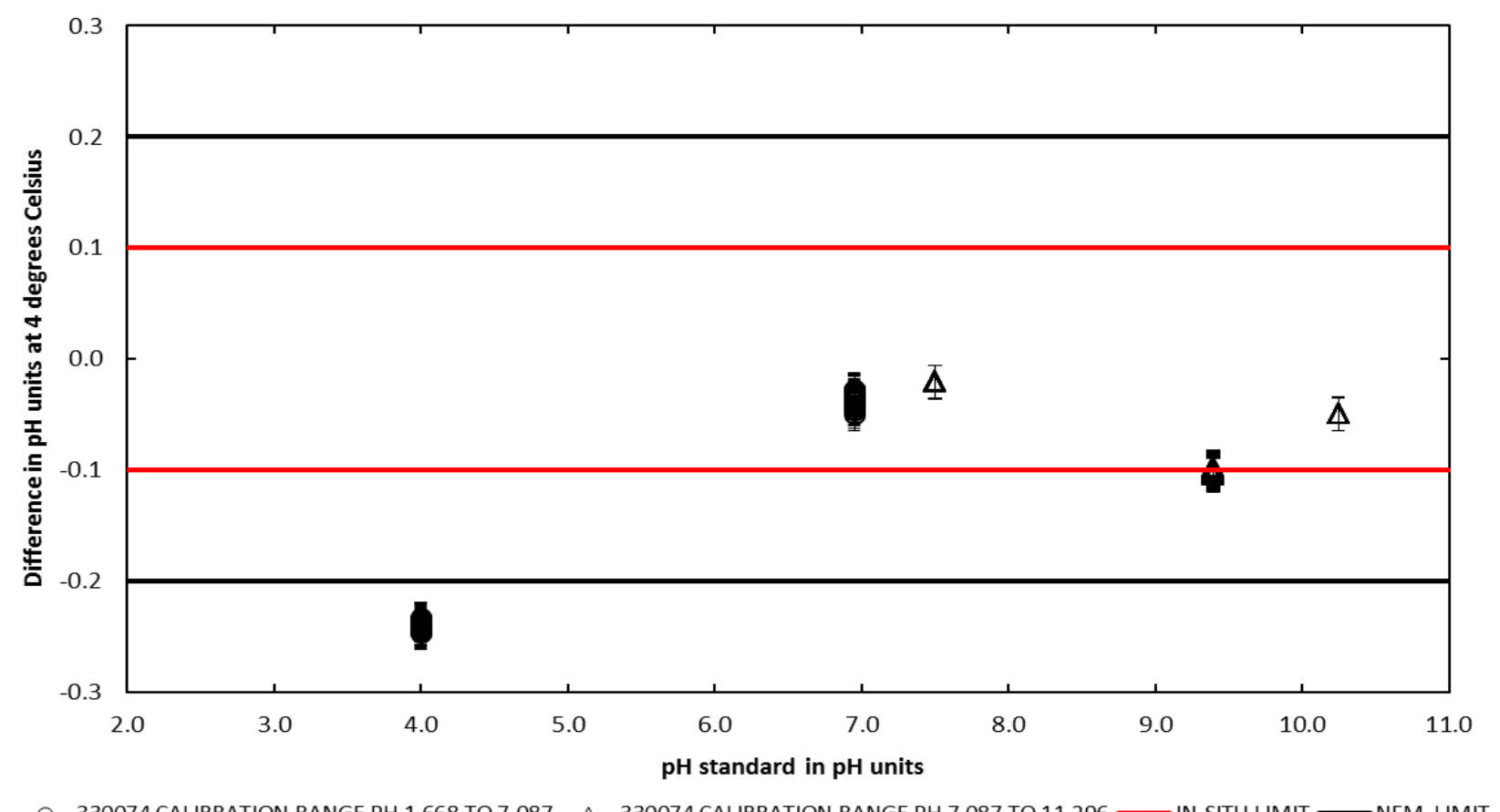

Figure 4. Graph showing difference in $\mathrm{pH}$ units between an In-Situ Aqua TROLL 400 (serial number 330074) pH sensor calibrated at two pH ranges and pH standards at 4 degrees Celsius plotted with manufacturer and the U.S. Geological Survey "National Field Manual for the Collection of Water-Quality Data" (NFM) accuracy limits. Error bars reflect the combined accuracy of the calibration and test standards. 


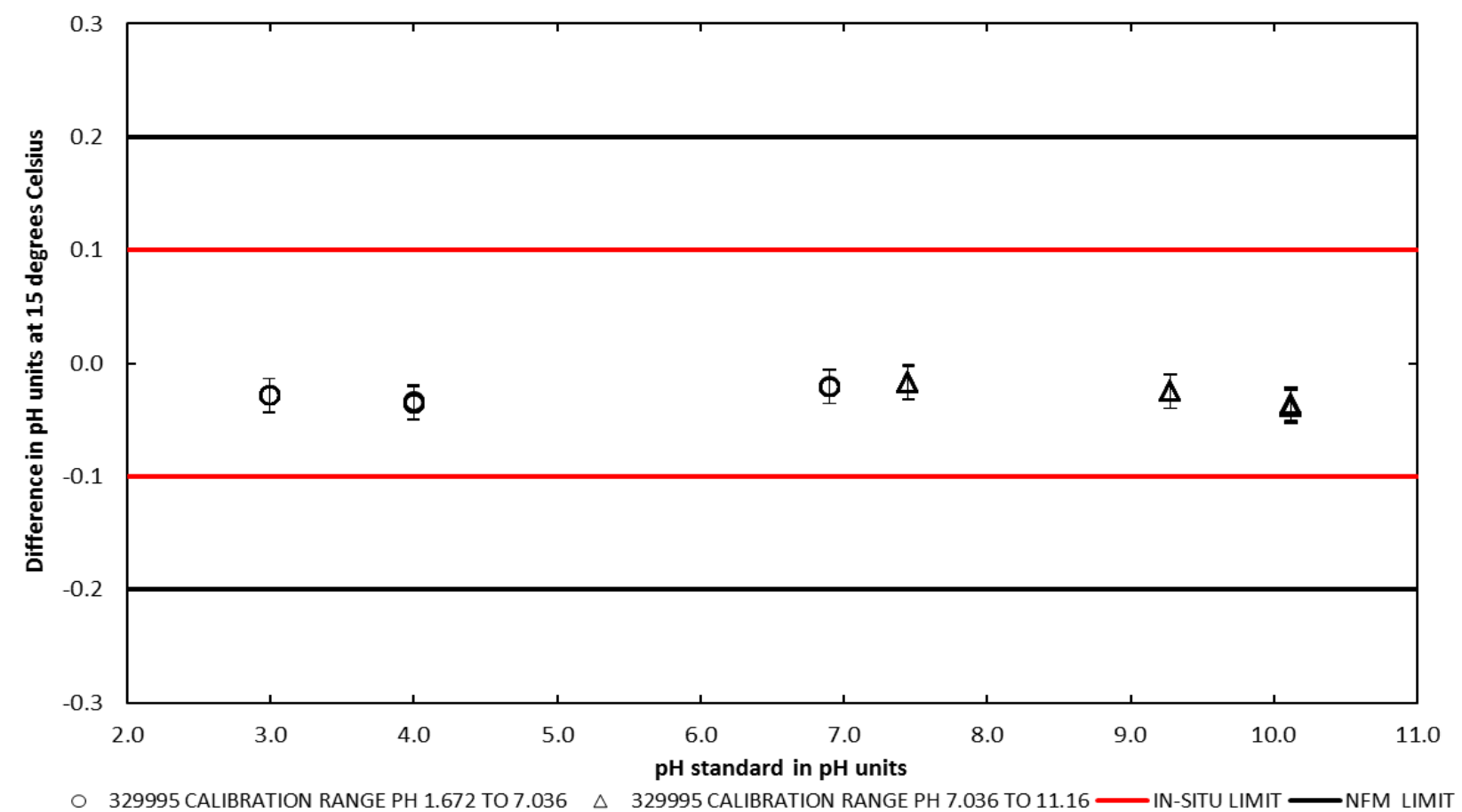

Figure 5. Graph showing difference in pH units between an In-Situ Aqua TROLL 400 (serial number 329995) $\mathrm{pH}$ sensor calibrated at two $\mathrm{pH}$ ranges and pH standards at 15 degrees Celsius plotted with manufacturer and the U.S. Geological Survey "National Field Manual for the Collection of Water-Quality Data" (NFM) accuracy limits. Error bars reflect the combined accuracy of the calibration and test standards. 


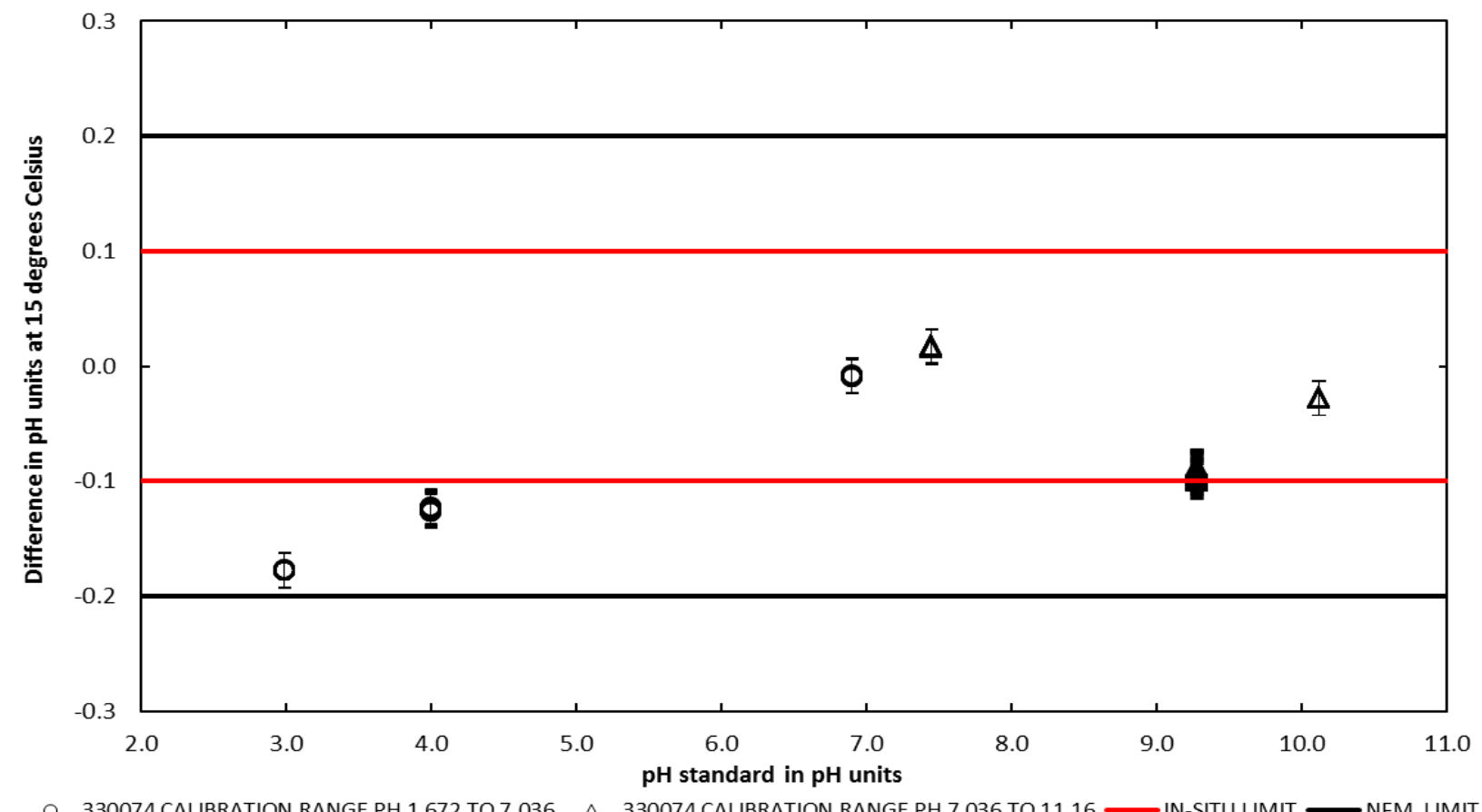

Figure 6. Graph showing difference in $\mathrm{pH}$ units between an In-Situ Aqua TROLL 400 (serial number 330074) $\mathrm{pH}$ sensor calibrated at two pH ranges and pH standards at 15 degrees Celsius plotted with manufacturer and the U.S. Geological Survey "National Field Manual for the Collection of Water-Quality Data" (NFM) accuracy limits. Error bars reflect the combined accuracy of the calibration and test standards. 


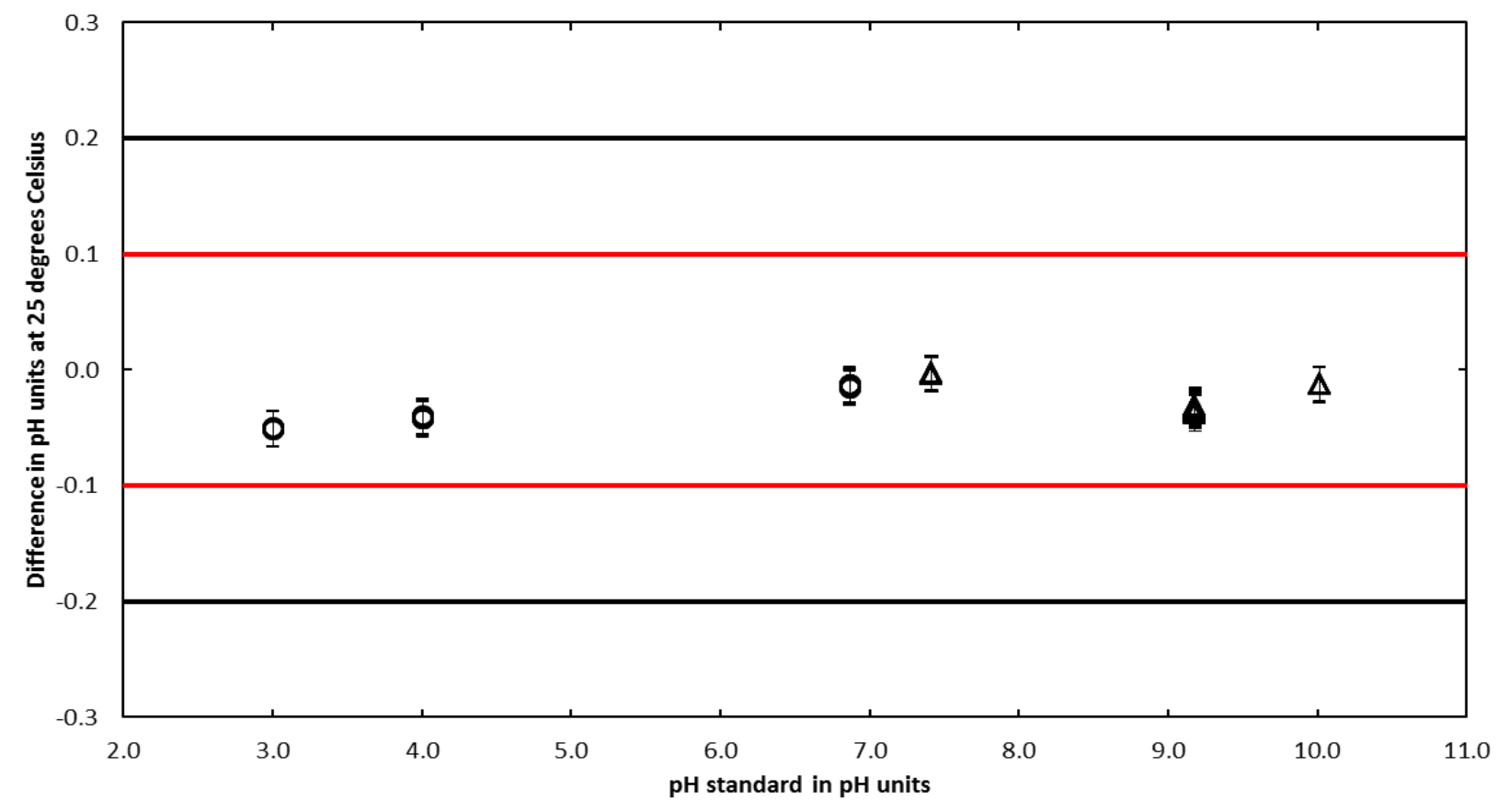

○ 329995 CALIBRATION RANGE PH 1.679 TO $7.00 \quad \Delta \quad 329995$ CALIBRATION RANGE PH 7.00 TO 11.00 IIN-SITU LIMIT $\longrightarrow$ NFM LIMIT

Figure 7. Graph showing difference in pH units between an In-Situ Aqua TROLL 400 (serial number 329995) $\mathrm{pH}$ sensor calibrated at two $\mathrm{pH}$ ranges and pH standards at 25 degrees Celsius plotted with manufacturer and the U.S. Geological Survey "National Field Manual for the Collection of Water-Quality Data" (NFM) accuracy limits. Error bars reflect the combined accuracy of the calibration and test standards. 


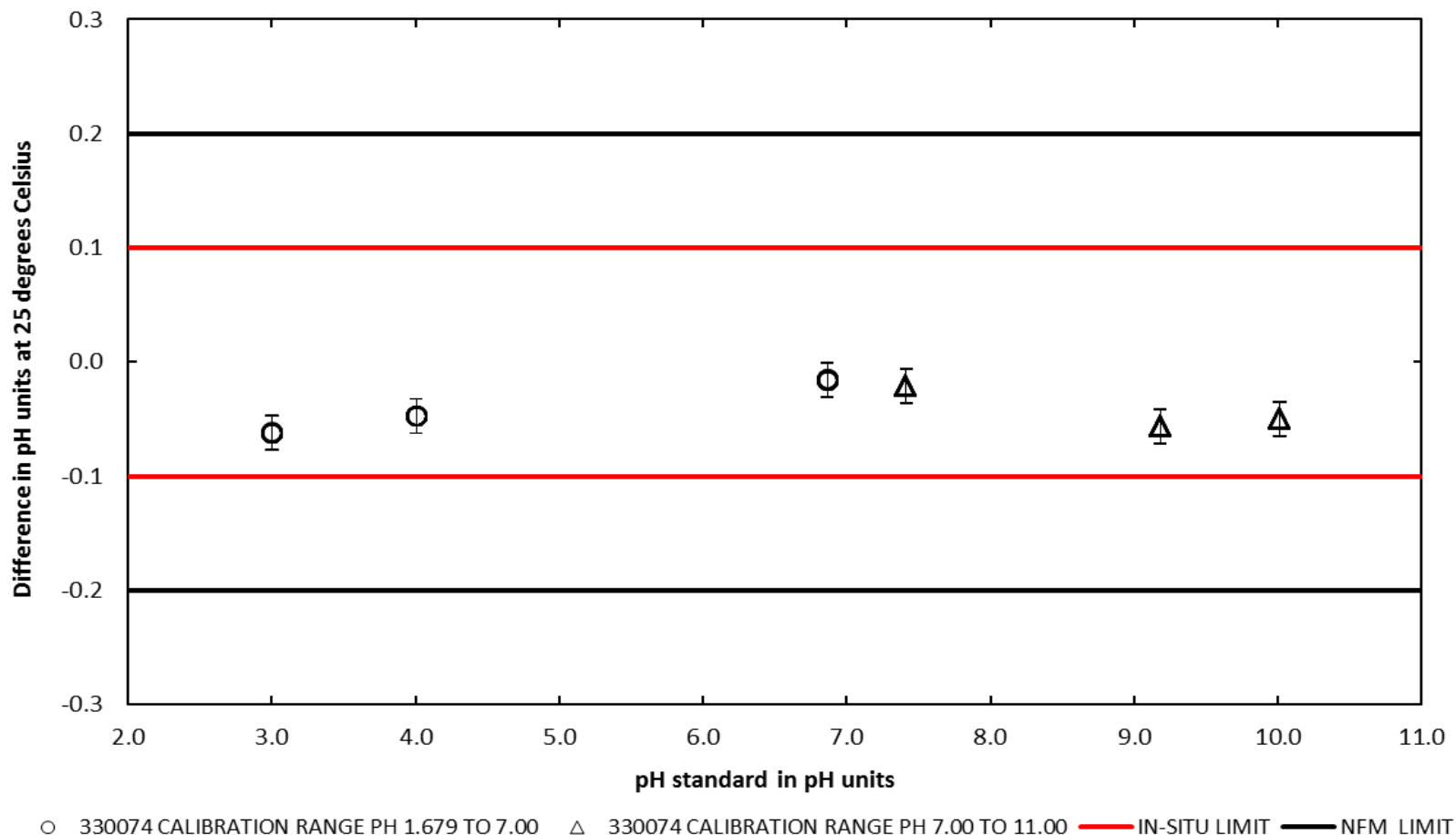

Figure 8. Graph showing difference in pH units between an In-Situ Aqua TROLL 400 (serial number 330074) $\mathrm{pH}$ sensor calibrated at two $\mathrm{pH}$ ranges and pH standards at 25 degrees Celsius plotted with manufacturer and the U.S. Geological Survey "National Field Manual for the Collection of Water-Quality Data" (NFM) accuracy limits. Error bars reflect the combined accuracy of the calibration and test standards. 


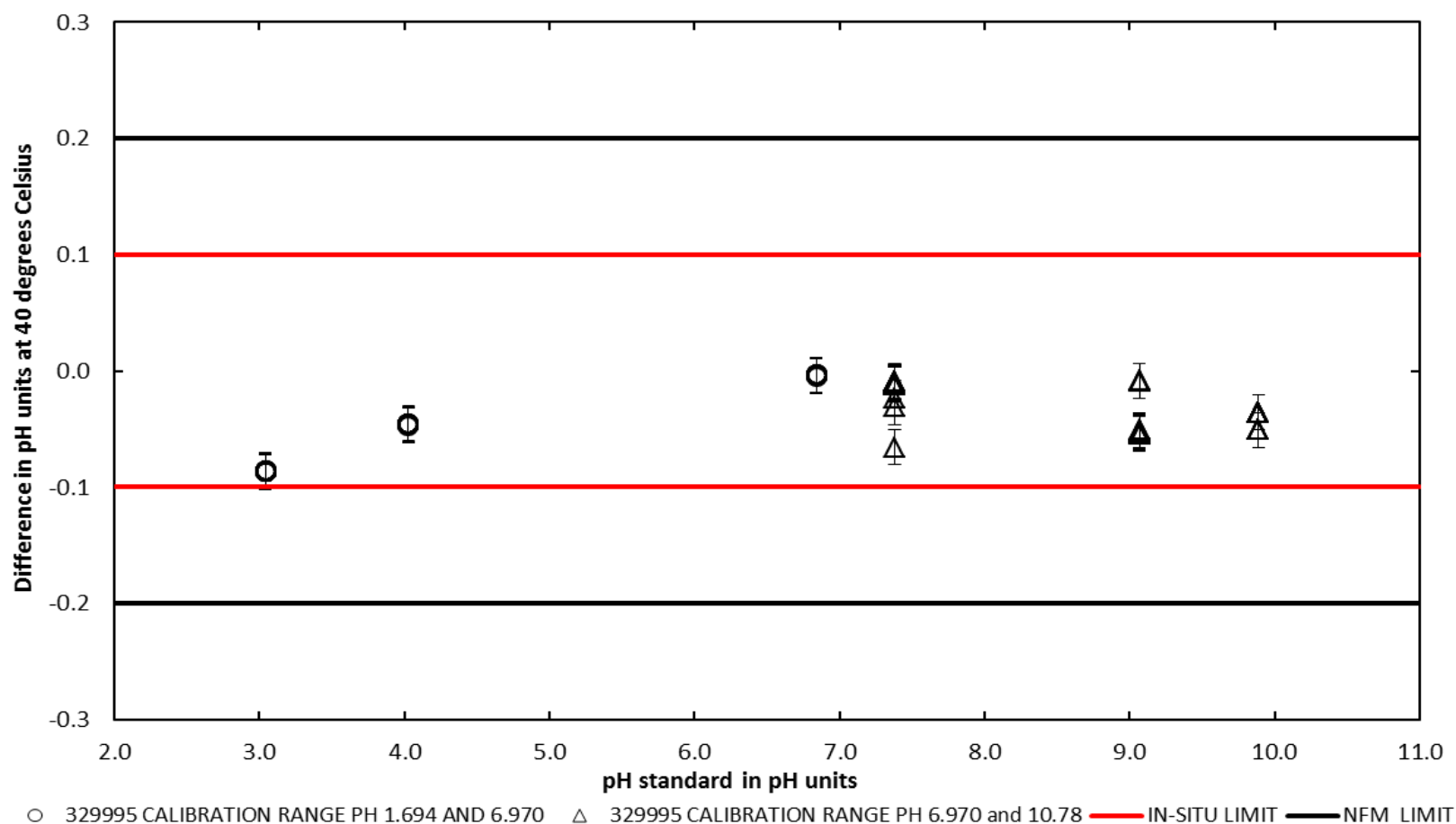

Figure 9. Graph showing difference in pH units between an In-Situ Aqua TROLL 400 (serial number 329995) $\mathrm{pH}$ sensor calibrated at two $\mathrm{pH}$ ranges and pH standards at 40 degrees Celsius plotted with manufacturer and the U.S. Geological Survey "National Field Manual for the Collection of Water-Quality Data" (NFM) accuracy limits. Error bars reflect the combined accuracy of the calibration and test standards. 


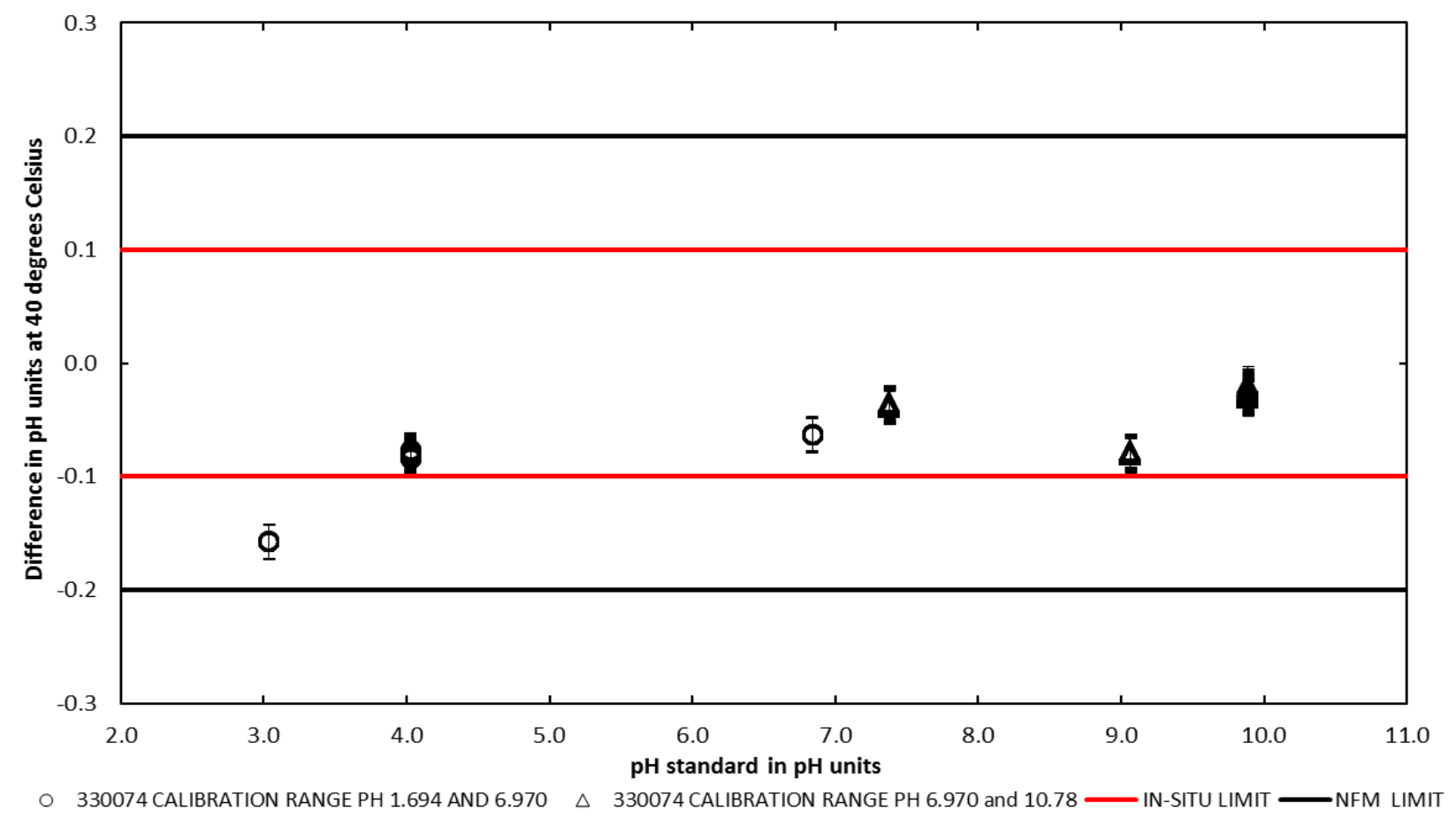

Figure 10. Graph showing difference in pH units between an In-Situ Aqua TROLL 400 (serial number 330074) $\mathrm{pH}$ sensor calibrated at two $\mathrm{pH}$ ranges and $\mathrm{pH}$ standards at 40 degrees Celsius plotted with manufacturer and the U.S. Geological Survey "National Field Manual for the Collection of Water-Quality Data" (NFM) accuracy limits. Error bars reflect the combined accuracy of the calibration and test standards.

\section{Specific Conductance at $25^{\circ} \mathrm{C}$}

Figures 11 through 18 show the percent difference between the sensor reading and the test standard value during SC testing at $4{ }^{\circ} \mathrm{C}, 15^{\circ} \mathrm{C}, 25^{\circ} \mathrm{C}$, and $40^{\circ} \mathrm{C}$. Measurements are plotted with error bars that reflect the combined calibration and test standards' accuracy and the uncertainty inherent in the applied temperature correction. This uncertainty arises because the temperature correction coefficient from Standard Methods $2510 \mathrm{~B}$ is only approximately the same as that of the $\mathrm{KCl}$ test standards. The further the test temperature deviates from $25^{\circ} \mathrm{C}$, the greater the uncertainty in the temperature correction applied to the $\mathrm{KCl}$ test standard measurement (Eaton and others, 2005). At $4{ }^{\circ} \mathrm{C}$ (figs. 11 and 12), the Aqua TROLL 400 met the NFM recommendations (Radtke and others, 2005) in all SC values tested. The Aqua TROLL 400 met the manufacturer's specifications, except at 99,918 $\mu \mathrm{S} / \mathrm{cm}$ (fig. 12), where 330074 exceeded the manufacturer's specifications. At $15^{\circ} \mathrm{C}$ (figs. 13 and 14), the Aqua TROLL 400 was within the NFM recommendations at all SC values tested, except at $99.9 \mu \mathrm{S} / \mathrm{cm}$ (fig. 13), where 329995 exceeded the NFM recommendations and the manufacturer's specifications and 330074 (fig.14) exceeded the manufacturer's specifications at $99.9 \mu \mathrm{S} / \mathrm{cm}$ and $99,918 \mu \mathrm{S} / \mathrm{cm}$. At $25^{\circ} \mathrm{C}$ (figs. 15 and 16), the Aqua TROLL 400 met the NFM recommendations at all SC values tested and met the manufacturer's specifications, except for 329995 at $99,918 \mu \mathrm{S} / \mathrm{cm}$ and 330074 at $1,412 \mu \mathrm{S} / \mathrm{cm}, 9994 \mu \mathrm{S} / \mathrm{cm}$, and 99,918 $\mu \mathrm{S} / \mathrm{cm}$. At $40{ }^{\circ} \mathrm{C}$ (figs. 17 and 18), the Aqua TROLL 400 met the NFM recommendations at all SC values tested, except for 329995 (fig. 17) at 
$99.9 \mu \mathrm{S} / \mathrm{cm}$, and met the manufacturer's specifications only at $99,918 \mu \mathrm{S} / \mathrm{cm}$. Overall, the Aqua TROLL 400 met the NFM recommendations in 93.7 percent of the SC standards tested and met the manufacturer's accuracy specifications in 56.2 percent of the SC standards tested.

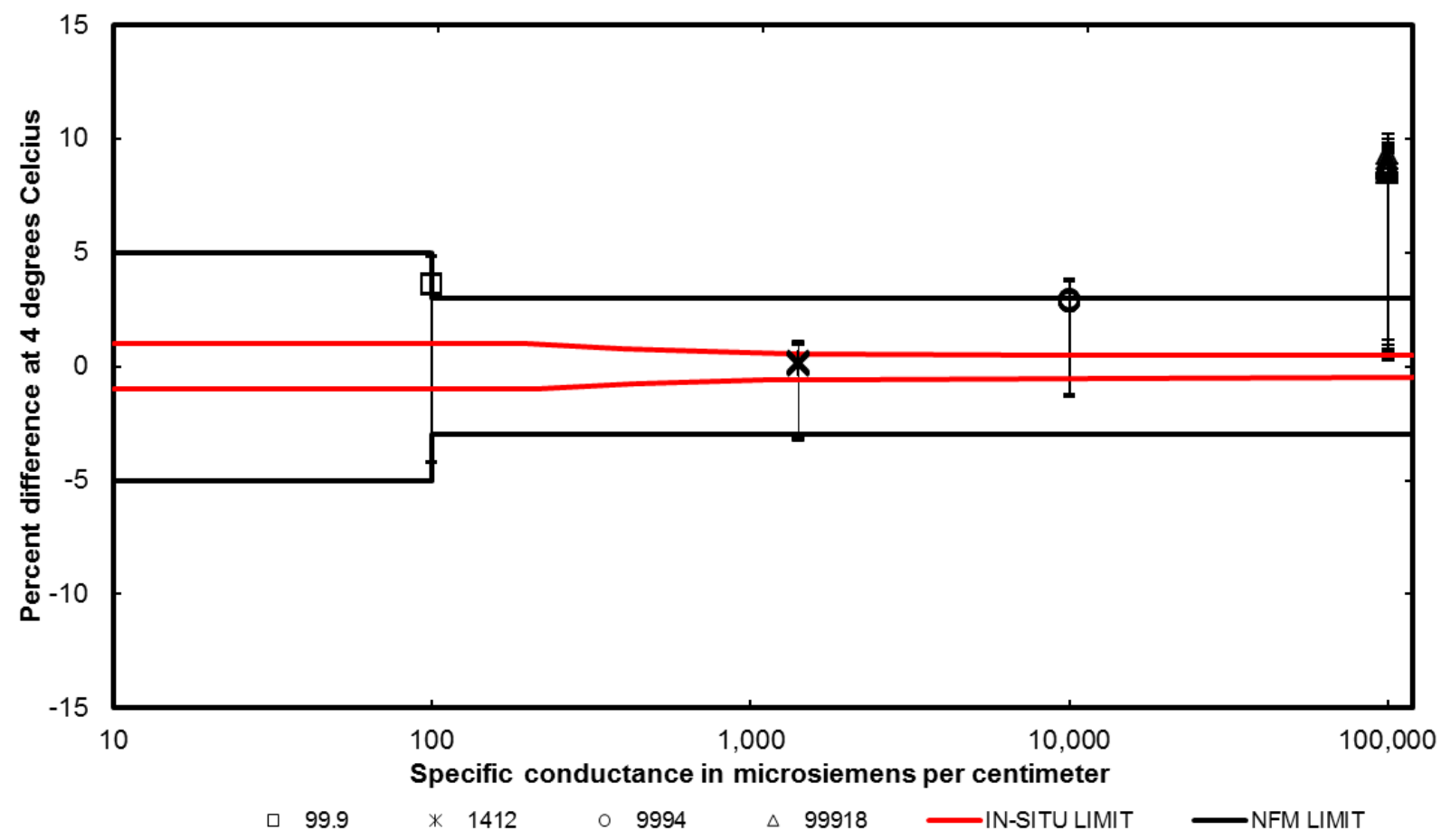

Figure 11. Graph showing percent difference between an In-Situ Aqua TROLL 400 (serial number 329995) specific conductance sensor and specific conductance standards at 4 degrees Celsius plotted with manufacturer and the U.S. Geological Survey "National Field Manual for the Collection of Water-Quality Data" (NFM) accuracy limits. Error bars reflect the combined uncertainty of the calibration and test standards and the uncertainty inherent in the applied temperature correction. 


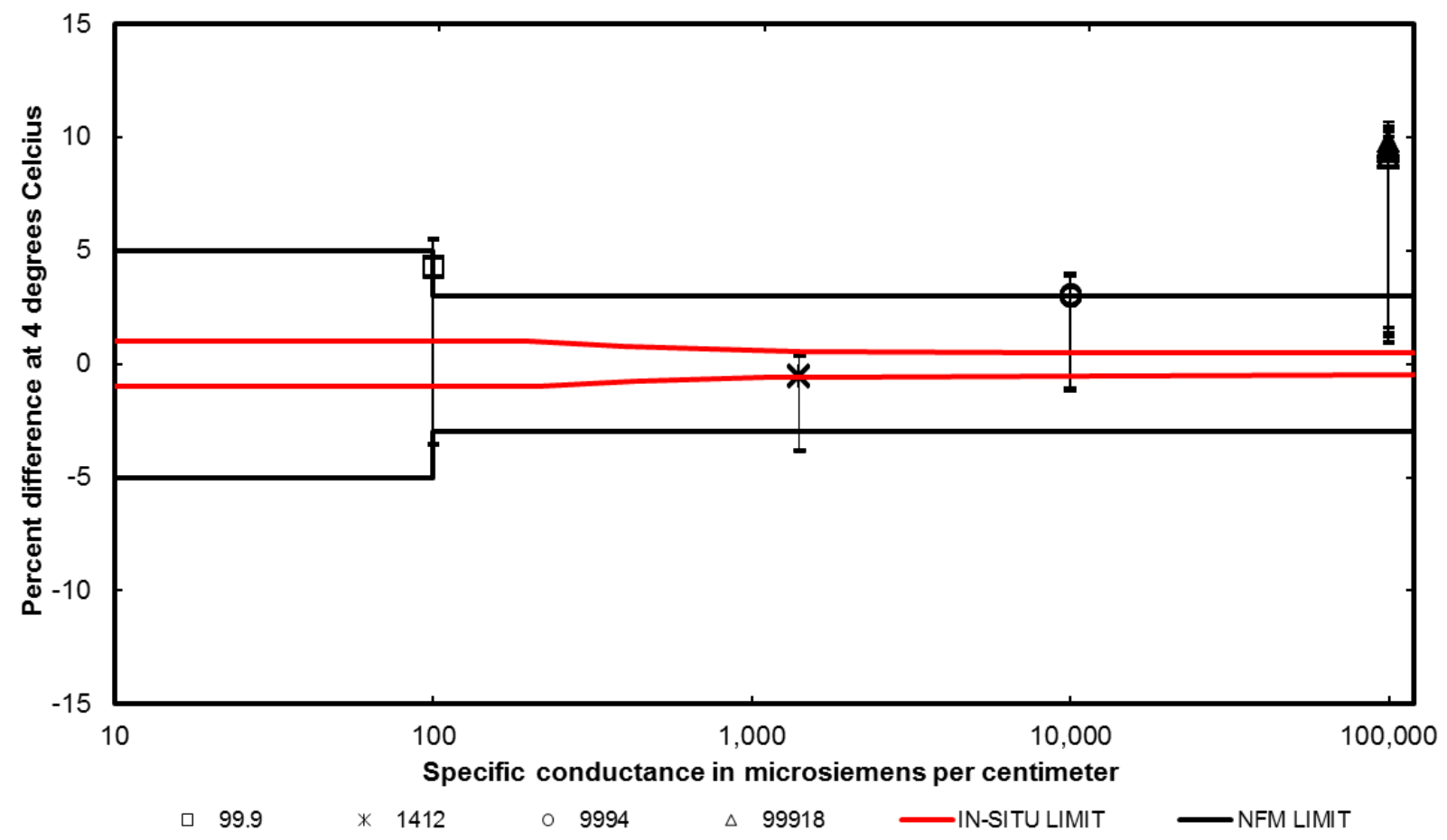

Figure 12. Graph showing percent difference between an In-Situ Aqua TROLL 400 (serial number 330074) specific conductance sensor and specific conductance standards at 4 degrees Celsius plotted with manufacturer and the U.S. Geological Survey "National Field Manual for the Collection of Water-Quality Data" (NFM) accuracy limits. Error bars reflect the combined uncertainty of the calibration and test standards and the uncertainty inherent in the applied temperature correction. 


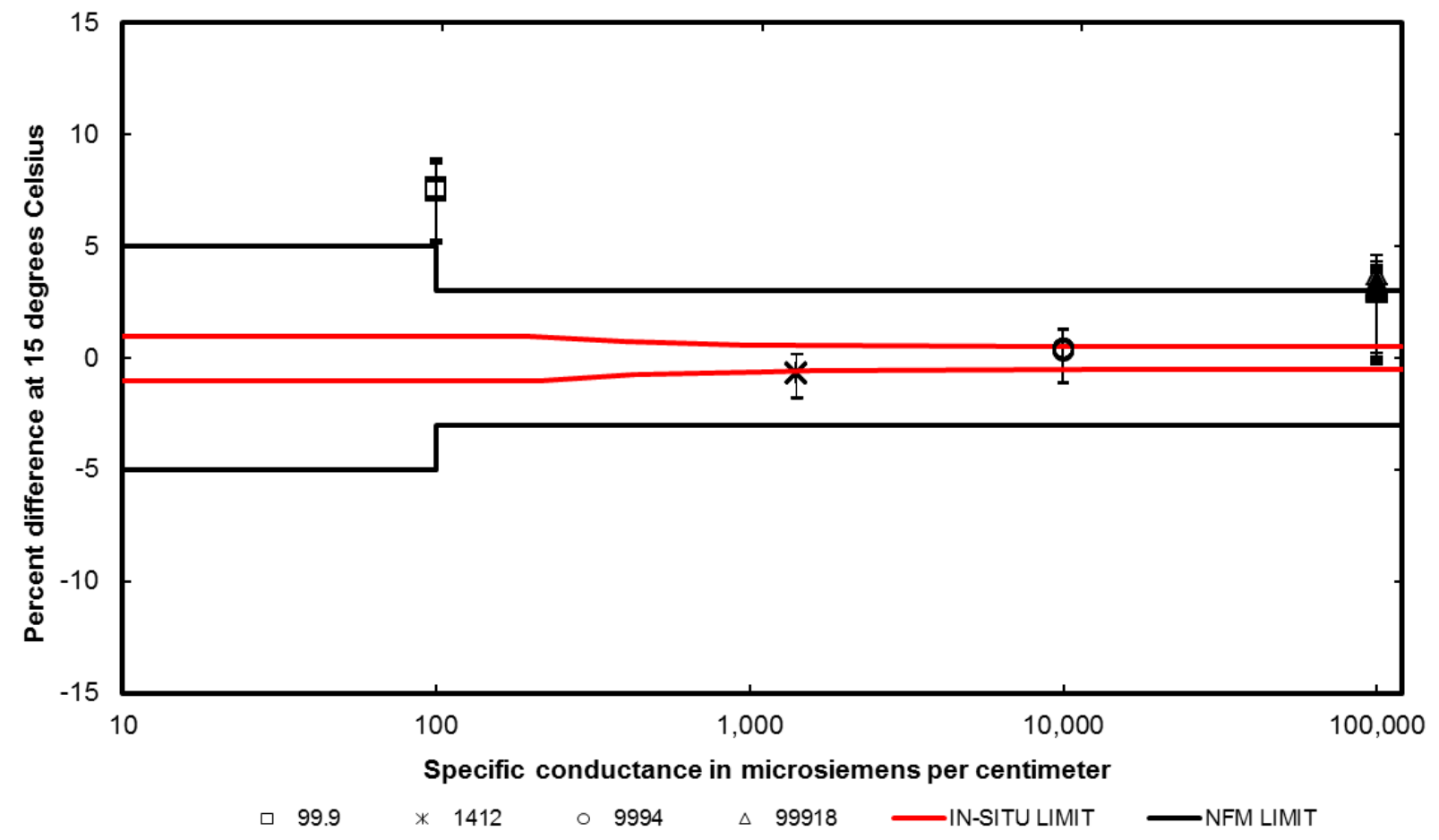

Figure 13. Graph showing percent difference between an In-Situ Aqua TROLL 400 (serial number 329995) specific conductance sensor and specific conductance standards at 15 degrees Celsius plotted with manufacturer and the U.S. Geological Survey "National Field Manual for the Collection of WaterQuality Data" (NFM) accuracy limits. Error bars reflect the combined uncertainty of the calibration and test standards and the uncertainty inherent in the applied temperature correction. 


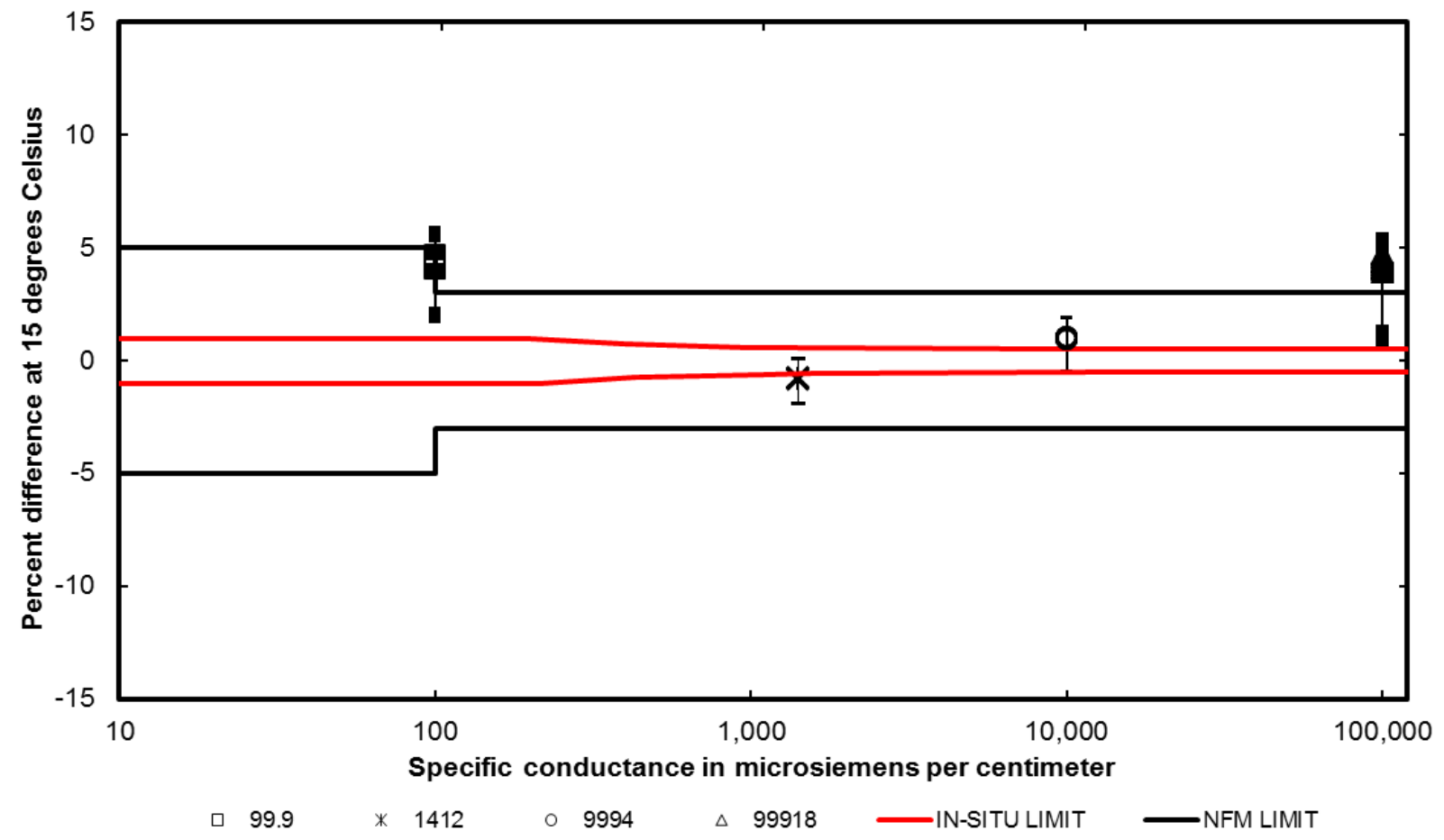

Figure 14. Graph showing percent difference between an In-Situ Aqua TROLL 400 (serial number 330074) specific conductance sensor and specific conductance standards at 15 degrees Celsius plotted with manufacturer and the U.S. Geological Survey "National Field Manual for the Collection of WaterQuality Data" (NFM) accuracy limits. Error bars reflect the combined uncertainty of the calibration and test standards and the uncertainty inherent in the applied temperature correction. 


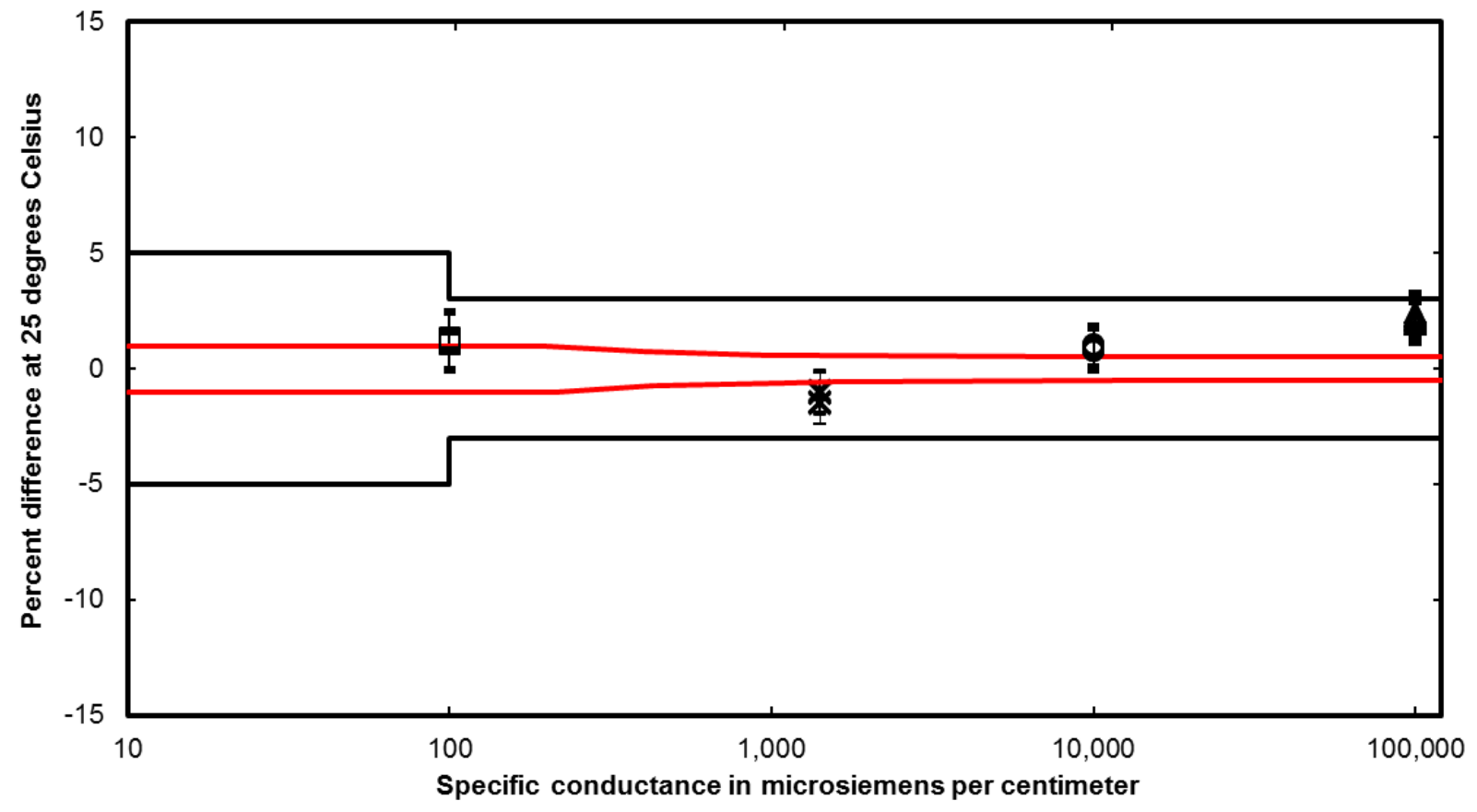

$99.9 \quad * \quad 1412 \quad \circ 9994 \quad \Delta \quad 99918 \quad$ IN-SITU LIMIT $\quad$ NFM LIMIT

Figure 15. Graph showing percent difference between an In-Situ Aqua TROLL 400 (serial number 329995) specific conductance sensor and specific conductance standards at 25 degrees Celsius plotted with manufacturer and the U.S. Geological Survey "National Field Manual for the Collection of WaterQuality Data" (NFM) accuracy limits. Error bars reflect the combined uncertainty of the calibration and test standards. 


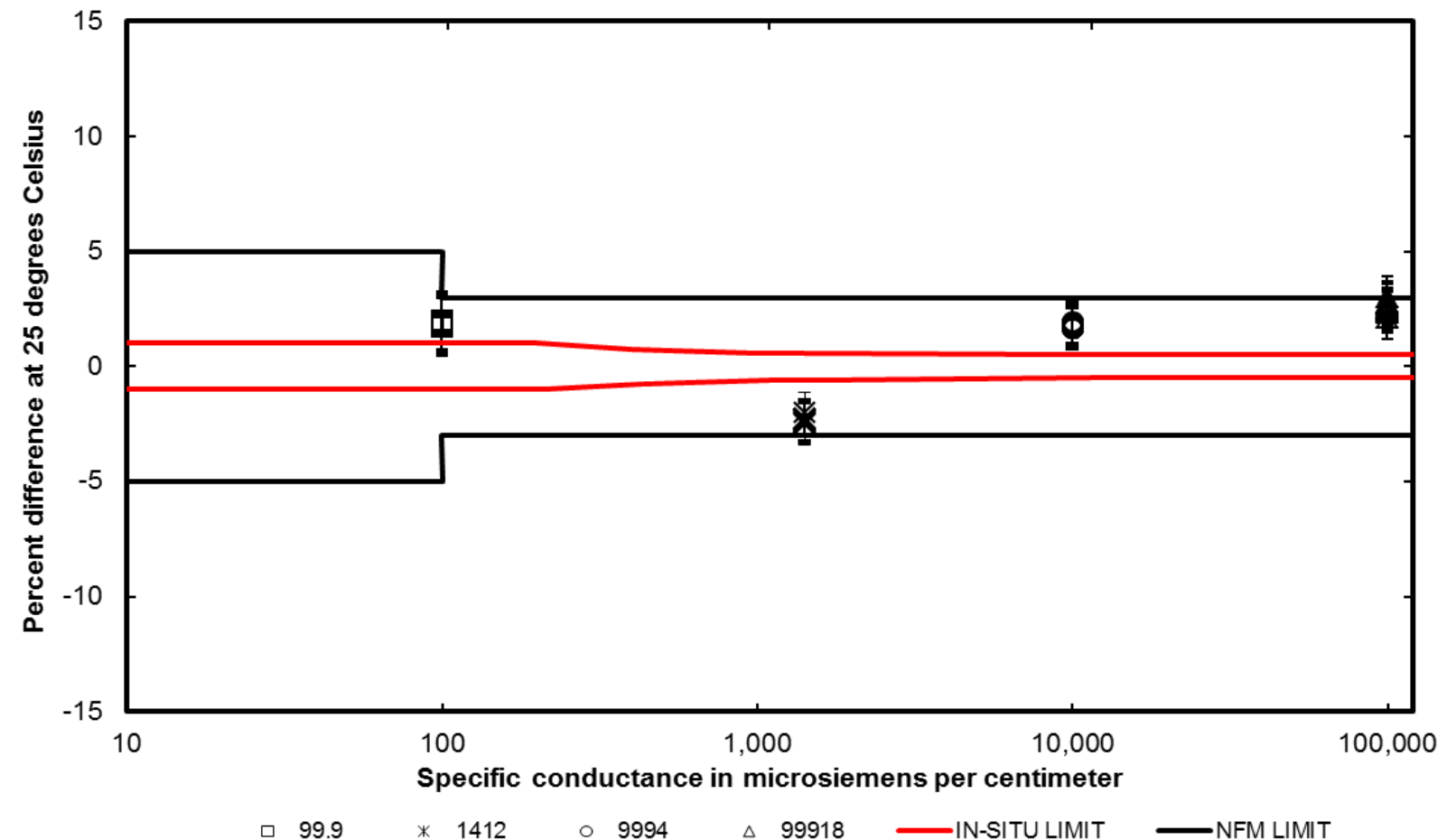

Figure 16. Graph showing percent difference between an In-Situ Aqua TROLL 400 (serial number 330074) specific conductance sensor and specific conductance standards at 25 degrees Celsius plotted with manufacturer and the U.S. Geological Survey "National Field Manual for the Collection of WaterQuality Data" (NFM) accuracy limits. Error bars reflect the combined uncertainty of the calibration and test standards. 


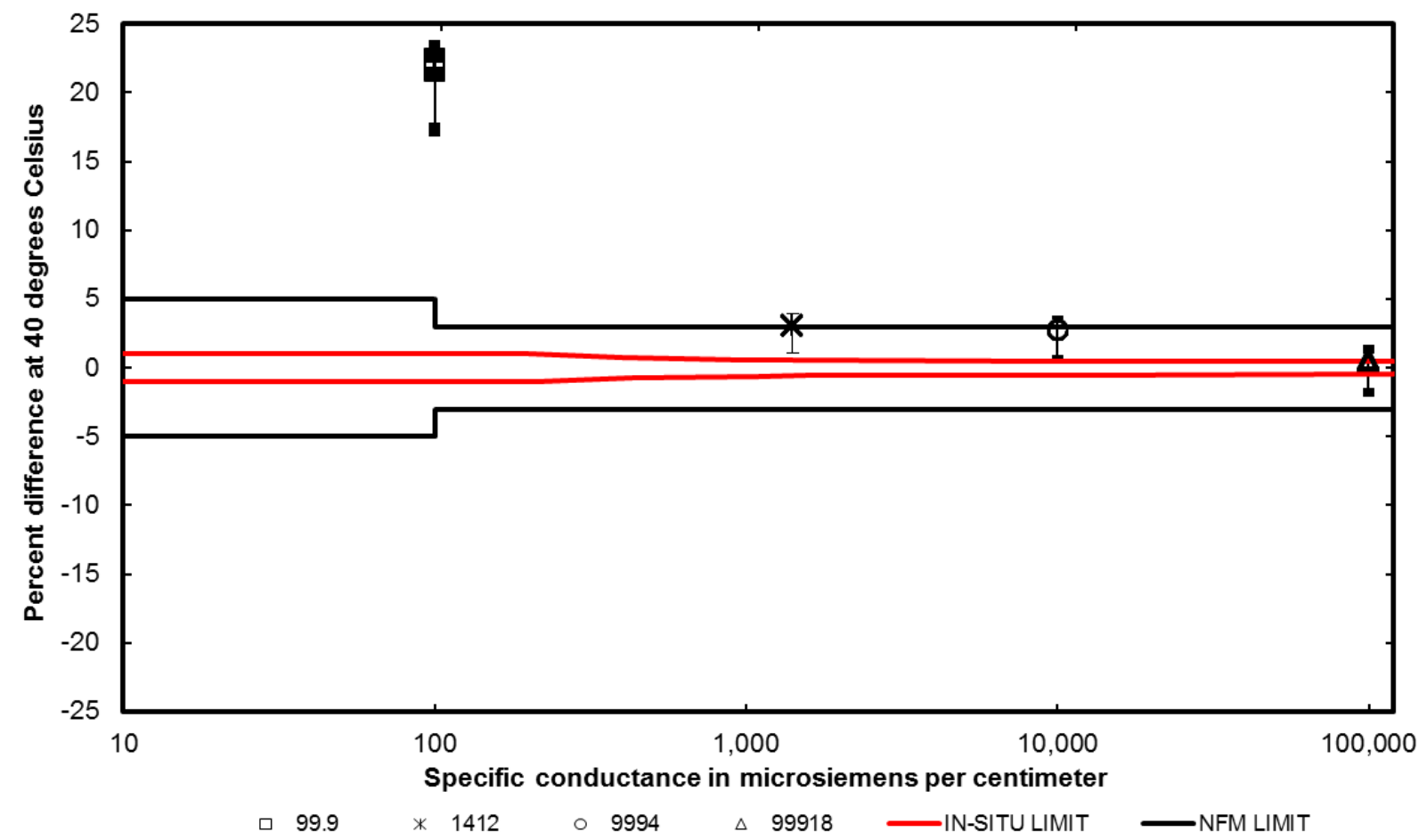

Figure 17. Graph showing percent difference between an In-Situ Aqua TROLL 400 (serial number 329995) specific conductance sensor and specific conductance standards at 40 degrees Celsius plotted with manufacturer and the U.S. Geological Survey "National Field Manual for the Collection of WaterQuality Data" (NFM) accuracy limits. Error bars reflect the combined uncertainty of the calibration and test standards and the uncertainty inherent in the applied temperature correction. 


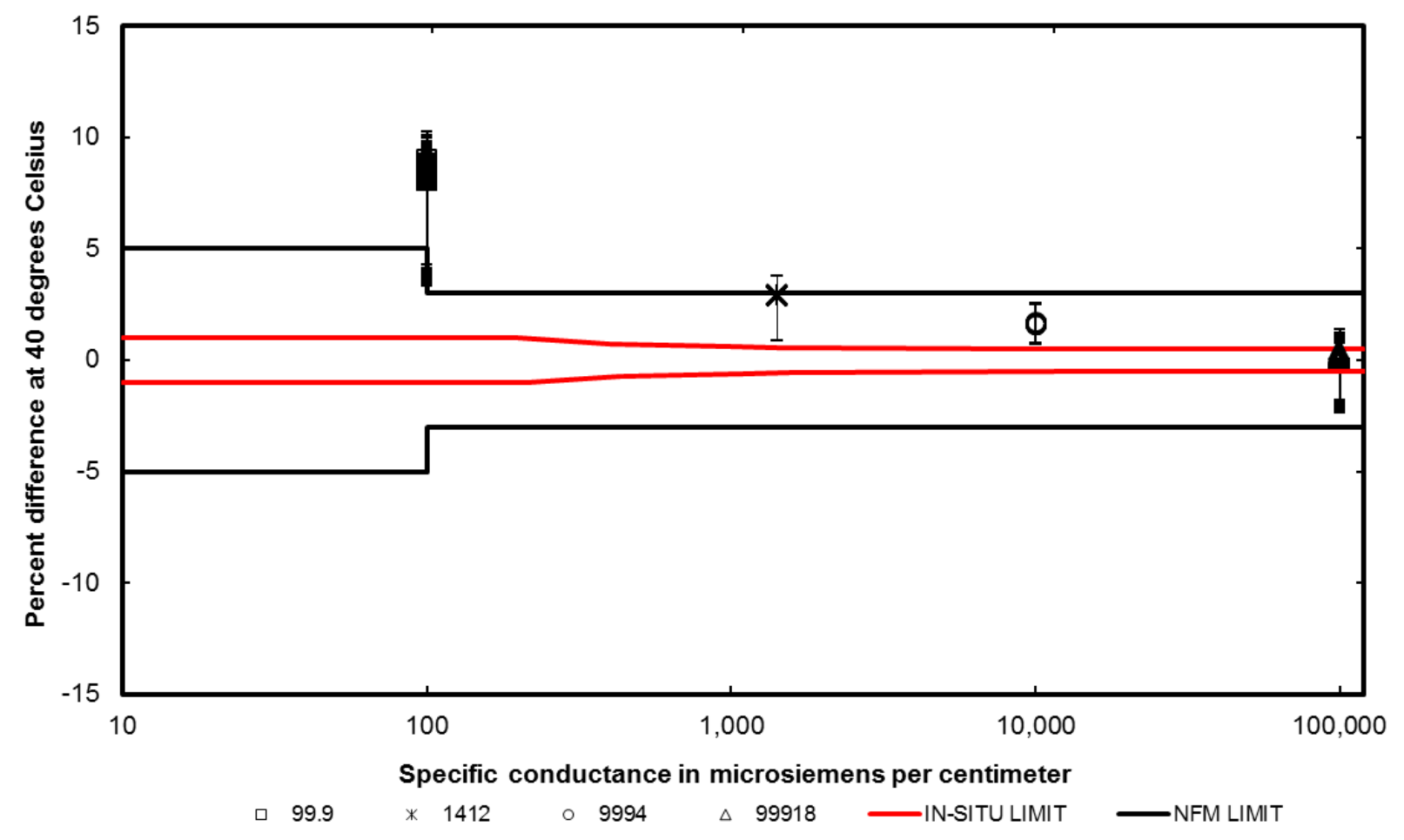

Figure 18. Graph showing percent difference between an In-Situ Aqua TROLL 400 (serial number 330074) specific conductance sensor and specific conductance standards at 40 degrees Celsius plotted with manufacturer and the U.S. Geological Survey "National Field Manual for the Collection of WaterQuality Data" (NFM) accuracy limits. Error bars reflect the combined uncertainty of the calibration and test standards and the uncertainty inherent in the applied temperature correction.

\section{Dissolved Oxygen}

Figure 19 shows the difference in $\mathrm{DO}$ in $\mathrm{mg} / \mathrm{L}$ between the sensor reading and the theoretical DO value. The vertical error bars reflect the uncertainty in the calculated theoretical values for DO used as a reference standard. The Aqua TROLL 400 RDO sensor tested within the manufacturer specifications, except at $5.55 \mathrm{mg} / \mathrm{L}$, and met the NFM recommendations at all concentrations tested. 


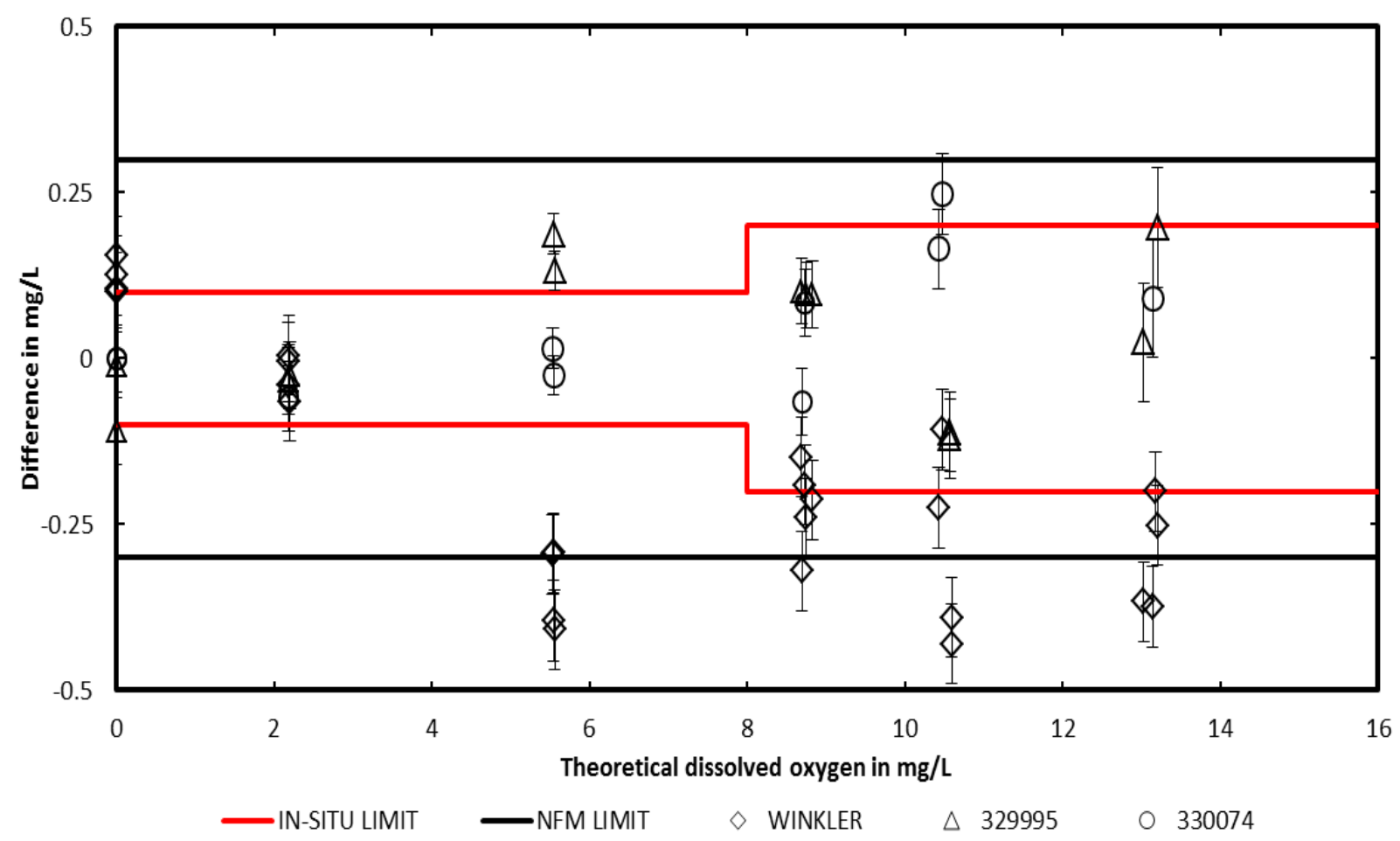

Figure 19. Graph showing difference in milligrams per liter (mg/L) between two In-Situ Aqua TROLL 400 RDO sensors (serial numbers 329995 and 330074) and theoretical dissolved oxygen concentrations plotted with manufacturer and the U.S. Geological Survey "National Field Manual for the Collection of WaterQuality Data" (NFM) accuracy limits. Error bars reflect the accuracy of the sensor calibration and accuracy of the calculated theoretical dissolved oxygen concentration.

\section{Field Test}

\section{Test Procedure}

An Aqua TROLL 400 (serial number 329995) used in the laboratory testing was deployed at the HIF's field test site (02492620 Pearl River at National Space Technology Laboratories (NSTL) Station, Mississippi)

(http://waterdata.usgs.gov/usa/nwis/uv?site_no=02492620) over a 6-week deployment. The test site is tidally affected, and depending on the discharge, wind, and tides, the river can be fresh, brackish, or salt water. The river can be well or poorly mixed and stratified in the water column.

The field test consisted of an In-Situ Aqua TROLL 400 deployed inside a stilling well for 6 weeks with biweekly maintenance. The permanently installed site sonde, a Hydrolab Data Sonde 5, was the field test standard. The test sonde was deployed adjacent to the site sonde in the stilling well at the same depth as the site sonde ( $10.5 \mathrm{feet}$ [ft] from the top of the stilling well). The test sonde was calibrated according to the NFM and the manufacturer's guidance for field deployment. Data, including temperature $\left({ }^{\circ} \mathrm{C}\right), \mathrm{pH}, \mathrm{SC}(\mu \mathrm{S} / \mathrm{cm})$, and dissolved oxygen $(\mathrm{mg} / \mathrm{L})$, were logged by a Design Analysis WaterLOG H-500XL every 15 minutes.

Biweekly maintenance of the Aqua TROLL 400 consisted of cleaning and calibration checks against standards. Fouling- and calibration-drift corrections for the sensors were calculated in accordance with USGS protocol for correction of field data (Wagner and others, 2006). 
The site sonde was maintained and checked weekly and calibrated as needed. Quality control (QC) checks during the field test consisted of comparison readings with a YSI 6920 V2-2 field reference sonde, temporarily deployed during each weekly site visit to determine fouling drift. The field reference sonde was carefully maintained and checked weekly against standards and calibrated as needed. The data from the test sonde were compared to the data from the Pearl River site sonde and the field reference sonde that was used for weekly QC checks. The test sonde was installed at the Pearl River site June 25, 2013, and removed August 6, 2013. During the deployment, as indicated by weekly vertical profiling at the gage, the river was well mixed.

The data from the site sonde and the test sonde used in this report for the field test comparison were not corrected for fouling or calibration drift. Previous field tests at the HIF have shown that applying fouling-drift or calibration-drift corrections to field-test data make comparison analysis unreliable. The uncorrected values for stage varied from a low of $-0.66 \mathrm{ft}$ to a high of $2.56 \mathrm{ft}$, and the uncorrected values for water temperatures measured by the site sonde ranged from 26.3 to $33.5^{\circ} \mathrm{C}$. The uncorrected values for $\mathrm{pH}$ values measured by the site sonde during the test ranged from 5.62 to 6.60 . The uncorrected values for $\mathrm{SC}$ values measured by the site sonde during the test ranged from 37 to $86 \mu \mathrm{S} / \mathrm{cm}$ and the uncorrected values for dissolved oxygen concentrations measured by the site sonde ranged from $4.35 \mathrm{mg} / \mathrm{L}$ to a high of $7.56 \mathrm{mg} / \mathrm{L}$.

The differences between the test sonde and the site sonde were calculated by subtracting the site sonde's value from the test sonde's readings observed (Difference $=$ test sonde - site sonde). Positive differences indicated a high bias in the test sonde data, and negative differences indicated a low bias in test sonde data.

The recommendations from table 6.8-5 of chapter 6 of the NFM, Use of Multiparameter Instruments for Routine Field Measurements (Gibs and others, 2007), have been adopted by the HIF as acceptance criteria for field testing water-quality sondes (table 5). Because each sonde's accuracy is assumed to meet at least the maximum criteria listed in table $6.8-5$, the acceptance criteria is equal to twice the criteria listed in the table. To meet the acceptance criteria, the differences between the Aqua TROLL 400 sonde's sensors and the site sonde's sensors should be less than or equal to the acceptance criteria. Measurement differences greater than the acceptance criteria indicated a failure to meet the criteria.

Table 5. Acceptance criteria for field comparison testing of the In-Situ Aqua TROLL 400 sonde and the Hydrolab Data Sonde 5 site sonde.

$\left[{ }^{\circ} \mathrm{C}\right.$, degree Celsius; $\mu \mathrm{S} / \mathrm{cm}$, microsiemen per centimeter, $\%$, percent; $\mathrm{mg} / \mathrm{L}$, milligram per liter]

\begin{tabular}{ll}
\hline \multicolumn{1}{c}{ Sensor parameter } & Acceptance criteria \\
\hline Temperature $\left({ }^{\circ} \mathrm{C}\right)$ & \pm 0.4 \\
$\mathrm{pH}$ (pH units) & \pm 0.6 \\
Dissolved oxygen $(\mathrm{mg} / \mathrm{L})$ & \pm 0.6 \\
Specific conductance $(\mu \mathrm{S} / \mathrm{cm})$ & $\pm 10 \%$ of reading \\
\hline
\end{tabular}




\section{Test Results}

The test sonde temperature measurements were within $\pm 0.4^{\circ} \mathrm{C}$ of the site sonde measurements during the 6-week field test, with minimal differences (fig. 20). There were some notable spikes during weeks one, five, and six of the field test, which could have been the result of a temporarily stratified water column and river boat traffic. The Troll's $\mathrm{pH}$ measurements agreed with the site sonde during the 6-week field test (fig. 21). Shifts in the site sonde's measured $\mathrm{pH}$ occurred regularly due to biofouling that was occurring during the field test. The Troll's SC measurements showed a high bias relative to the site sonde but were within the accuracy limits during most of the field test (fig. 22). Differences in measured data between the Troll and the site sonde exceeded the test limits during the $2 \mathrm{~d}$ and 6 th week of the field test, by as much as 28 percent (18 uS/cm) (fig. $22 A$ ).

The DO measurements/concentrations for the test sonde agreed with the site sonde during the 6-week field test (fig. 23). The test sonde DO concentrations drifted downward relative to the site sonde during the first week, and drifted upward relative to the site sonde during the second week. The test sonde DO concentrations remained constant relative to the site sonde for the rest of the field test. 

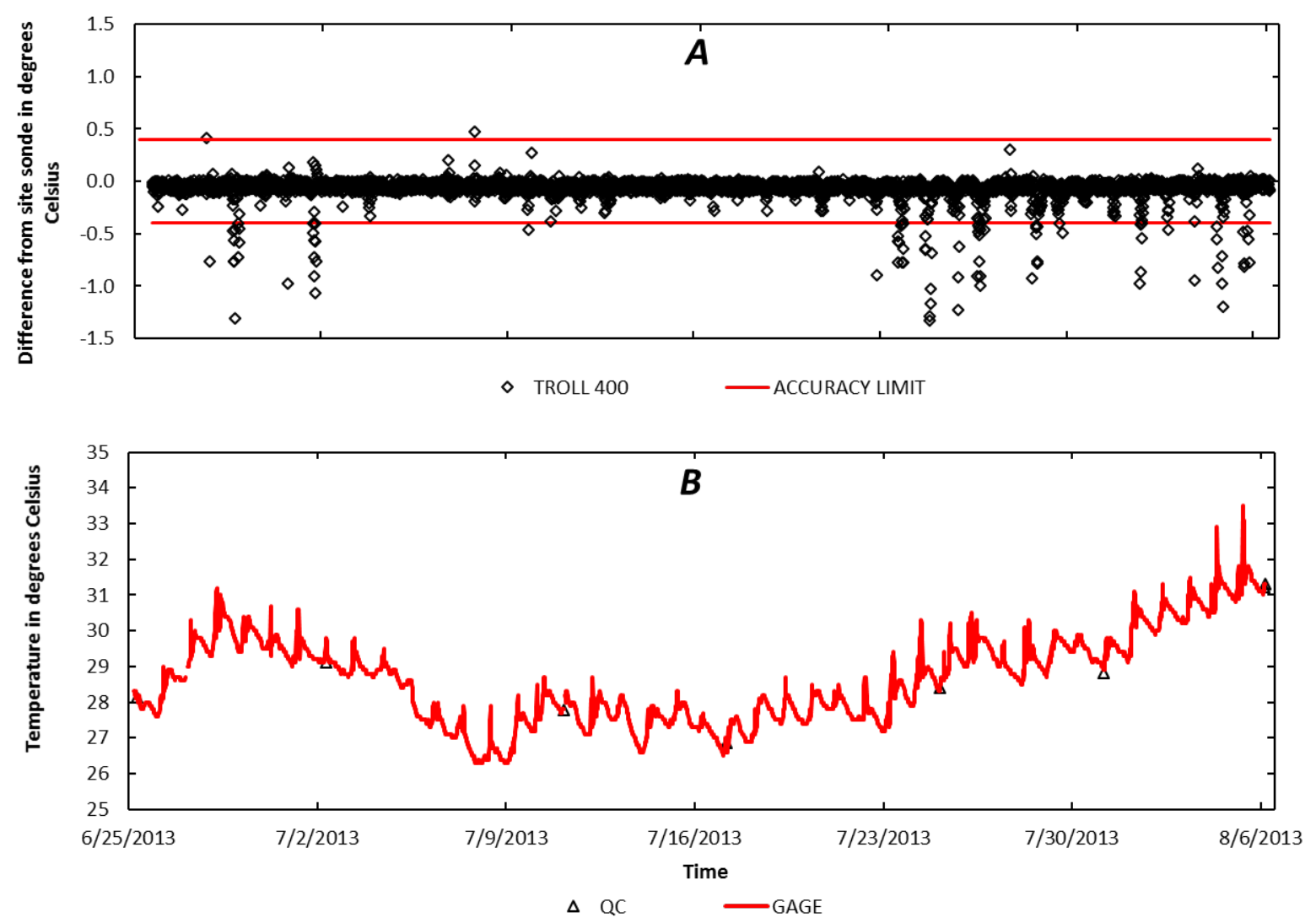

Figure 20. Graphs showing A, Temperature differences between an In-Situ Aqua TROLL 400 test sonde and the site sonde at U.S. Geological Survey (USGS) station 02492620 (Pearl River at National Space Technology Laboratories [NSTL] Station, Mississippi) versus time ( 6 weeks), and $B$, Temperature versus time for the site sonde and a YSI 6920 V2-2 Quality Control (QC) sonde. Differences for the top chart were calculated by subtracting the site sonde's reading from the test sonde's reading (Difference $=$ test sonde site sonde). Accuracy limits are twice the limits recommended in table $6.8-5$ of chapter 6 of the USGS "National Field Manual for the Collection of Water-Quality Data" (NFM). 

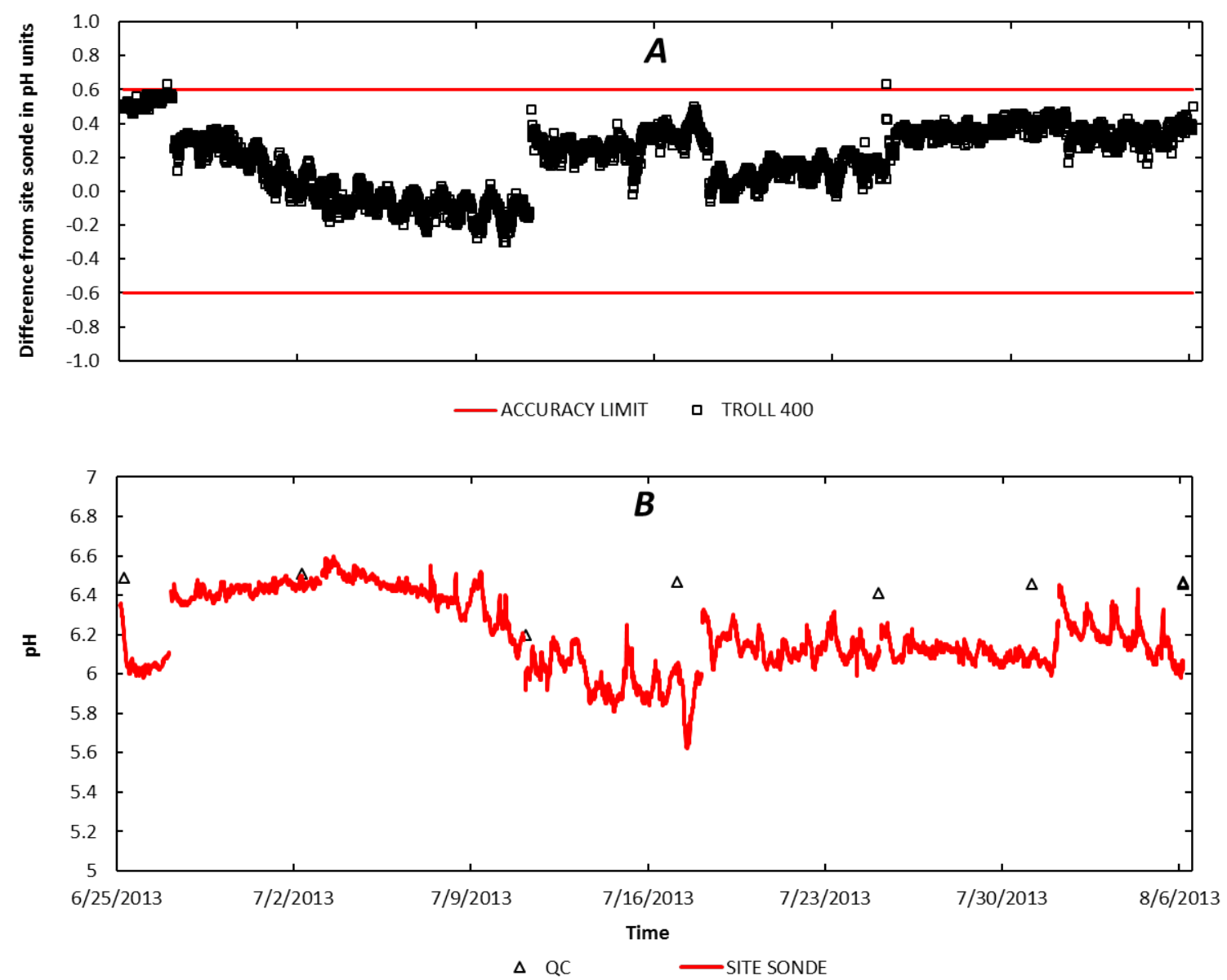

Figure 21. Graphs showing A, pH differences between an In-Situ Aqua TROLL 400 test sonde and the site sonde at U.S. Geological Survey station (USGS) 02492620 (Pearl River at National Space Technology Laboratories [NSTL] Station, Mississippi) versus time (6 weeks), and $B, \mathrm{pH}$ versus time for the site sonde and a YSI 6920 V2-2 Quality Control (QC) sonde. Differences for the top chart were calculated by subtracting the site sonde's reading from the test sonde's reading (Difference $=$ test sonde - site sonde). Accuracy limits are twice the limits recommended in table 6.8-5 of chapter 6 of the USGS "National Field Manual for the Collection of Water-Quality Data" (NFM). 

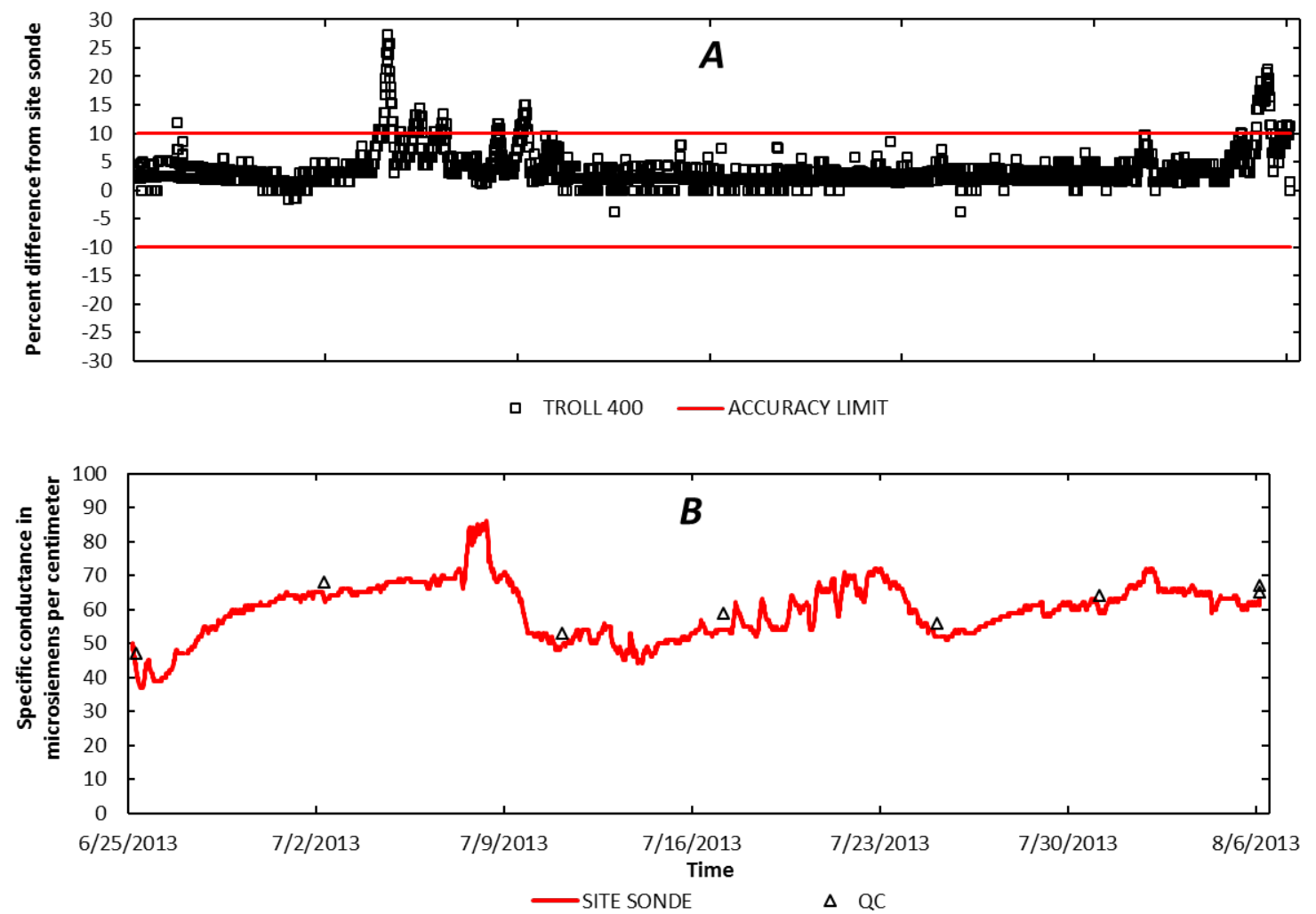

Figure 22. Graphs showing A, Specific conductance percent differences between an In-Situ Aqua TROLL 400 test sonde and the site sonde at U.S. Geological Survey (USGS) station 02492620 (Pearl River at National Space Technology Laboratories [NSTL] Station, Mississippi) versus time (6 weeks), and $B$, Specific conductance vs. time for the site sonde and a YSI 6920 V2-2 Quality Control (QC) sonde. Differences for the top chart were calculated by subtracting the site sonde's reading from the test sonde's reading, dividing by the site sonde's reading and multiplying the result by 100 (Percent Difference $=$ [test sonde - site sonde)/site sonde] x 100). Accuracy limits are twice the limits recommended in Table 6.8-5 of chapter 6 of the USGS "National Field Manual for the Collection of Water-Quality Data" (NFM). 

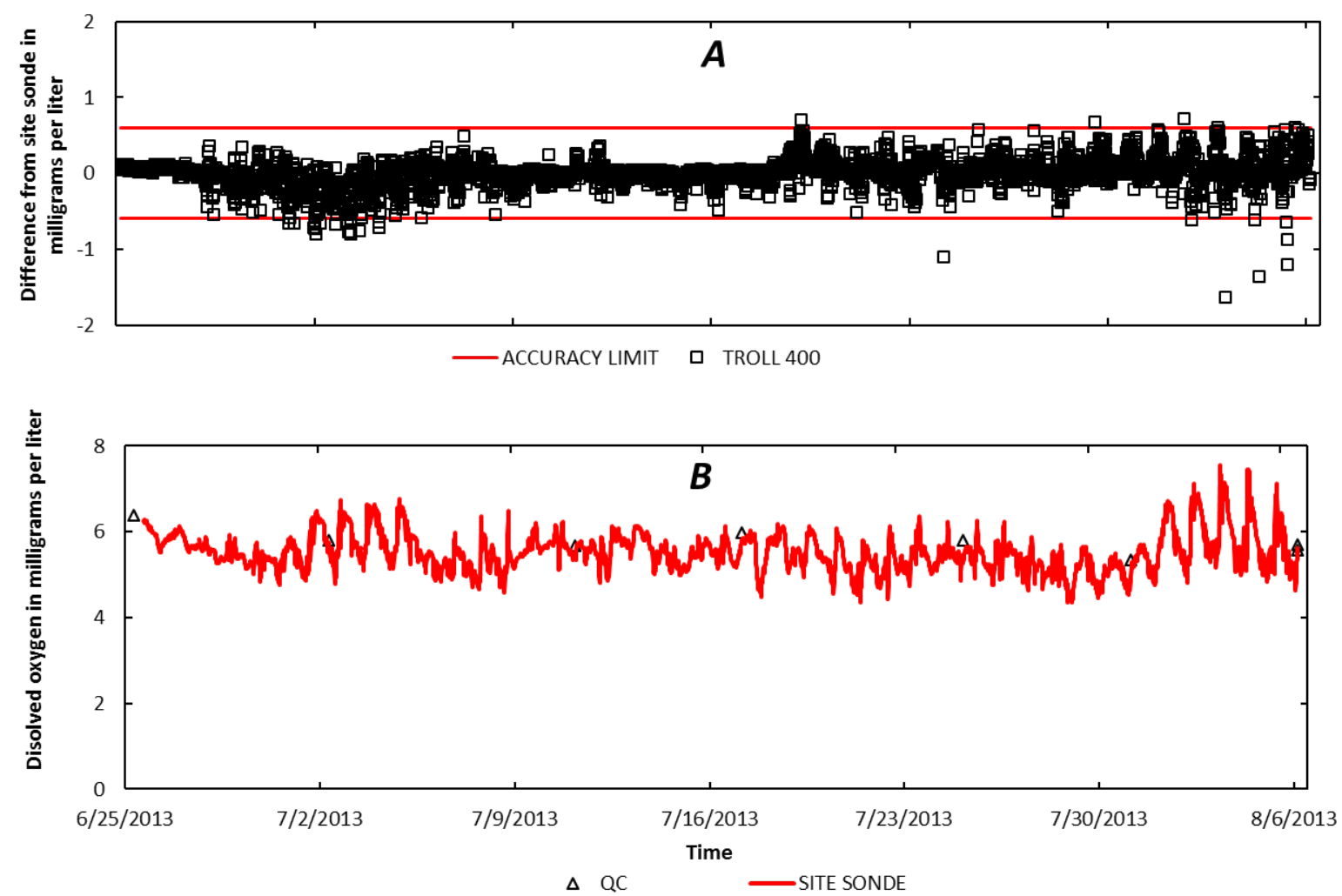

Figure 23. Graphs showing A, Dissolved oxygen differences between an In-Situ Aqua TROLL 400 test sonde and the site sonde at U.S. Geological Survey (USGS) station 02492620 (Pearl River at National Space Technology Laboratories [NSTL] Station, Mississippi) versus time (6 weeks), and B, Dissolved oxygen vs. time for the site sonde and a YSI 6920 V2-2 Quality Control (QC) sonde. Differences for the top chart were calculated by subtracting the site sonde's reading from the test sonde's reading (Difference $=$ test sonde - site sonde). Accuracy limits are twice the limits recommended in table 6.8-5 of chapter 6 of the USGS "National Field Manual for the Collection of Water-Quality Data" (NFM). 
The summary statistics (table 6) for the 6-week test period show good agreement of temperature, $\mathrm{pH}, \mathrm{SC}$, and DO measurements between the Aqua TROLL 400 and the site sonde. The difference between the mean temperature for the test sonde data and the mean temperature for the site sonde was $-0.06{ }^{\circ} \mathrm{C}$. The difference between the mean $\mathrm{pH}$ for the test sonde data and the mean $\mathrm{pH}$ for the site sonde was $0.2 \mathrm{pH}$ units. The mean difference between the test sonde and site sonde SC was $9 \mu \mathrm{S} / \mathrm{cm}$ (3.3 percent). The difference between the mean DO for the test sonde and the site sonde was $0.0 \mathrm{mg} / \mathrm{mL}$ when compared to the site sonde.

Table 6. Summary statistics for the test sonde, an In-Situ Aqua TROLL 400 (serviced biweekly), and the site sonde, a Hydrolab Data Sonde 5 (serviced every week), at U.S. Geological Survey Station 02492620 Pearl River at National Space Technology Laboratories (NSTL) Station, Mississippi, over a 6-week deployment.

\begin{tabular}{|c|c|c|c|}
\hline Statistic & Site sonde & Test sonde & Difference \\
\hline \multicolumn{4}{|c|}{ Temperature in degrees Celsius } \\
\hline Mean & 28.65 & 28.59 & -0.06 \\
\hline Maximum & 33.50 & 32.52 & -0.98 \\
\hline Minimum & 26.30 & 26.22 & -0.08 \\
\hline Standard deviation & 1.26 & 1.24 & -0.02 \\
\hline Data point count & 3,999 & 4,027 & - \\
\hline \multicolumn{4}{|c|}{$\mathrm{pH}$ in $\mathrm{pH}$ units } \\
\hline Mean & 6.20 & 6.40 & 0.2 \\
\hline Maximum & 6.60 & 6.86 & 0.26 \\
\hline Minimum & 5.62 & 5.95 & 0.33 \\
\hline Standard deviation & 0.18 & 0.17 & -0.01 \\
\hline Data point count & 3,999 & 4,027 & - \\
\hline \multicolumn{4}{|c|}{ Specific conductance in microsiemens per centimeter } \\
\hline Mean & 60 & 62 & 2 \\
\hline Maximum & 86 & 95 & 9 \\
\hline Minimum & 37 & 38 & 1 \\
\hline Standard deviation & 8 & 9 & 1 \\
\hline Data point count & 3,999 & 4,027 & - \\
\hline \multicolumn{4}{|c|}{ Dissolved oxygen in milligrams per liter } \\
\hline Mean & 5.52 & 5.52 & 0 \\
\hline Maximum & 7.56 & 7.57 & 0.01 \\
\hline Minimum & 4.35 & 3.40 & -0.95 \\
\hline Standard deviation & 0.44 & 0.44 & 0.0 \\
\hline Data point count & 3,999 & 4,027 & - \\
\hline
\end{tabular}


Fouling- and calibration-drift data were collected from the Aqua TROLL 400 at the end of the field test. The fouling and calibration drift corrections (table 7) were calculated from the data in accordance with USGS protocol for the correction of field data (table 8) but not applied to the test sonde's data. Fouling corrections are calculated from the test sonde's precleaning and postcleaning measurements. Calibration-drift corrections are calculated from the test sonde's precalibration and postcalibration checks against known standards.

During the site visit on July 11, 2013, the fouling corrections were "Good" for $\mathrm{pH}$, and "Excellent" for SC and DO. During the site visit on July 25, 2013, the fouling corrections were "Fair" for $\mathrm{pH}$ and Good for SC and DO. During the final site visit on August, 6, 2013, the fouling correction for all of the sensors was Excellent. The sonde's calibration drift ratings computed after each site visit were Excellent, requiring no calibration during the field test.

Table 7. Fouling- and calibration-drift corrections for an In-Situ Aqua TROLL 400 after a 6-week deployment at U.S. Geological Survey Station 02492620 Pearl River at National Space Technology Laboratories (NSTL) Station, Mississippi, with maintenance every 2 weeks. The sonde was calibrated on June 21, 2013. The correction values were not applied to the sonde data.

\begin{tabular}{lccc}
\hline \multicolumn{1}{c}{ Correction } & $\mathrm{pH}$ & $\begin{array}{c}\text { Specific } \\
\text { conductance }\end{array}$ & $\begin{array}{c}\text { Dissolved } \\
\text { oxygen }\end{array}$ \\
\hline \multicolumn{4}{c}{ Maintenance date 07/11/13 } \\
\hline Fouling drift & 0.33 & $2 \%$ & $2.24 \%$ \\
Calibration drift & 0.08 & $0.91 \%$ & $1.42 \%$ \\
\hline \multicolumn{5}{c}{ Maintenance date 07/25/13 } \\
\hline Fouling drift & 0.56 & $7.41 \%$ & $7.32 \%$ \\
Calibration drift & 0.05 & $1.11 \%$ & $0 \%$ \\
\hline \multicolumn{5}{c}{ Maintenance date 08/06/13 } \\
\hline Fouling drift & 0.10 & $1.56 \%$ & $0.86 \%$ \\
Calibration drift & 0.12 & $0.05 \%$ & $0.2 \%$ \\
\hline
\end{tabular}

Table 8. Accuracy ratings of continuous water-quality records, reprinted from U.S. Geological Survey Techniques and Methods 1-D3, table 18, 2006.

$\left[\leq\right.$, less than or equal to; \pm , plus or minus value shown; ${ }^{\circ} \mathrm{C}$, degree Celsius; $>$, greater than; $\%$, percent; $\mathrm{mg} / \mathrm{L}$, milligram per liter; $\mathrm{pH}$ unit, standard $\mathrm{pH}$ unit]

\begin{tabular}{lllll}
\hline $\begin{array}{c}\text { Measured field } \\
\text { parameter }\end{array}$ & \multicolumn{1}{c}{ Excellent } & Good & Fair & Poor \\
\hline Specific conductance & $\leq \pm 3 \%$ & $> \pm 3-10 \%$ & $> \pm 10-15 \%$ & $> \pm 15 \%$ \\
Dissolved oxygen & $\leq \pm 0.3 \mathrm{mg} / \mathrm{L}$ or & $> \pm 0.3-0.5 \mathrm{mg} / \mathrm{l}$ or & $> \pm 0.5-0.8 \mathrm{mg} / \mathrm{l} \mathrm{or}$ & $> \pm 0.8 \mathrm{mg} / \mathrm{lor}$ \\
& $\leq \pm 5 \%$, whichever & $> \pm 5-10 \%$, & $> \pm 10-15 \%$, & $> \pm 15 \%$, \\
& is greater & whichever is & whichever is & whichever is \\
& & greater & greater & greater \\
$\mathrm{pH}$ & $\leq \pm 0.2$ units & $> \pm 0.2-0.5$ units & $> \pm 0.5-0.8$ units & $> \pm 0.8$ units \\
\hline
\end{tabular}




\section{Summary}

The Aqua TROLL 400 was evaluated in the laboratory to validate the manufacturer's technical specifications for $\mathrm{pH}$, dissolved oxygen (DO), and specific conductance, and to determine compliance to the U.S. Geological Survey "National Field Manual for the Collection of Water-Quality Data" (NFM)'s recommendations for accuracy. SDI-12 communication was verified with a NR Systems SDI-12 Verifier, using software version 5.0.0.24 and Verifier firmware 1.6. The Aqua TROLL 400 was evaluated for field performance by deploying it at USGS site 02492620 adjacent to a well-maintained site sonde. The Aqua TROLL 400 was compliant with SDI-12 version 1.3. During laboratory testing of $\mathrm{pH}$, the Aqua TROLL 400 sonde met the NFM recommendations for $\mathrm{pH}$ at all values tested, except at 4 degrees Celsius $\left({ }^{\circ} \mathrm{C}\right)$ at $\mathrm{pH} 9.395$ and $\mathrm{pH} 3.998$. The Aqua TROLL 400 met the manufacturer specifications for $\mathrm{pH}$ at all values tested, except for $\mathrm{pH}$ buffer 3.998, 9.395, and 10.245 at $4{ }^{\circ} \mathrm{C} ; \mathrm{pH} 2.990$ and 3.998 at $15^{\circ} \mathrm{C}$; and $\mathrm{pH} 3.040$ at $40^{\circ} \mathrm{C}$. The Aqua TROLL 400 met the NFM recommendations at 93.7 percent of the SC values tested and met the manufacturer's accuracy specifications at 56.3 percent of the SC values tested. During the laboratory testing for DO, the Aqua TROLL 400 met the manufacturer's accuracy specifications, except at 5.55 milligrams per liter, and met the NFM recommendations for DO. The field-deployed Aqua TROLL 400 showed good agreement with the site sonde data and met the testing criteria with few exceptions.

\section{References Cited}

Benson, B.B., and Krause, Daniel, Jr., 1980, The concentration and isotopic fractionation of gases dissolved in freshwater in equilibrium with the atmosphere. 1. Oxygen: Limnology and Oceanography, v. 25, no. 4, p. 662-671.

Eaton, A.D., Clesceri, L.S., Rice, E.W., and Greenburg, A.E., eds., Standard Methods for the Examination of Water and Wastewater (21st ed.), 2005, p. 4-136-4-140.

Gibs, Jacob, Wilde, F.D., and Heckathorn, H.A., 2007, Use of multiparameter instruments for routine field measurements (ver. 1.1): U.S. Geological Survey Techniques of Water-Resources Investigations, book 9, chap. A6, section 6.8, accessed February 11, 2014, from http://water.usgs.gov/owq/FieldManual/Chapter6/6.8_contents.html.

Henry, William, 1803, Experiments on the quantity of gases absorbed by water, at different temperatures, and under different pressures: London, Philosophical Transactions of the Royal Society, no. 93, p. 29-274.

In-Situ, [2016], In-Situ Aqua TROLL 400 multiparameter probe spec sheet: In-Situ Web page, accessed May 27, 2016, at https://in-situ.com/.

Radtke, D.B., Davis, J.V., and Wilde, F.D., 2005, Specific electrical conductance: U.S.

Geological Survey Techniques of Water-Resources Investigations, book 9, chap. A6, section 6.3, accessed February 11, 2014, at http://water.usgs.gov/owq/FieldManual/Chapter6/6.3_contents.html.

Ritz, G.F., and Collins, J.A., 2008, pH: U.S. Geological Survey Techniques of Water-Resources Investigations, book 9, chap. A6, section 6.4, p. 21, accessed February 11, 2014, at http://water.usgs.gov/owq/FieldManual/Chapter6/6.4_contents.html.

Rounds, S.A., Wilde, F.D., and Ritz, G.F., 2013, Dissolved oxygen (ver. 3.0): U.S. Geological Survey Techniques of Water-Resources Investigations, book 9, chap. A6, sec. 6.2, accessed February 11, 2014, at http://water.usgs.gov/owq/FieldManual/Chapter6/6.2_ver3.pdf. 
United Kingdom Accreditation Service, 2007, M3003, The expression of uncertainty and confidence in measurement ( $2 \mathrm{~d}$ ed.), January: United Kingdom Accreditation Service, p. 1114.

Wagner, R.J., Boulger, R.W., Jr., Oblinger, C.J., and Smith, B.A., 2006, Guidelines and standard procedures for continuous water-quality monitors - Station operation, record computation, and data reporting: U.S. Geological Survey Techniques and Methods, book 1, chap. D3, p. 13 and p. 24-35, accessed February 11, 2014, at http://pubs.usgs.gov/tm/2006/tm1D3/pdf/TM1D3.pdf. 